\title{
Disputa suscitada en la ciudad de México, entre los Alcaldes del Crimen y los Ordinarios, por el Auto del año de 1819 que mandó a las actrices no vestir traje de hombre en las funciones del Coliseo. ${ }^{1}$
}

\author{
COMENTARIO
}

$\mathbf{E}$ N el Archivo General de la Nación, Archivo Histórico de Hacienda, en la ciudad de México, se halla el minucioso testimonio del expediente $^{2}$ con las contradictorias opiniones sustentadas por dos ramos de gobierno. Las polémicas, iniciadas como directa consecuencia de la cuestión de la autoridad de un Alcalde del Crimen de intervenir en los asuntos de los actores del Coliseo, trascendieron luego a otras esferas y a otras personas y, por lo tanto, nos suministran muchas noticias interesantes acerca del gobierno del Coliseo, el vestido de los actores y las actrices y las opiniones oficiales extendidas al campo puramente moral. Nada fué en efecto más importante que aclarar las reglas del Teatro para que se cumpliese con más puntualidad lo que determinara el Superior Gobierno. ${ }^{3}$ Resume el documento muchos de los Reglamentos expedidos en España y México, ${ }^{4}$ porque, a fin de contestar a lo afirmado por el Alcalde Ordinario, sus contradictores se sirvieron de ellos para dar más valor a sus alegaciones, dejando así datos que constituyen una parte indispensable de la historia del Coliseo ${ }^{5}$ en particular y del teatro mexicano en general. En suma, se encuentran condensadas en ellos las costumbres, ideas morales y tradiciones que inducian a los oficiales a intervenir en la dirección de la Casa de Comedias. Por no merecer menos las 
declaraciones, oficios, dictámenes y reales órdenes ể pro y contra, transcribo el expediente íntegro.

El origen de la disputa se debió a un paso - nluy curioso para nosotros, hombres del siglo $\mathrm{xx}$ - que tuvo por objeto mantener la moralidad y buenas costumbres entre las gentes de teatro, sobre todo entre las actrices, prohibiendo a éstas llevar en los tablados el traje del sexo masculino. ${ }^{6} \mathrm{El}$ señor don Juan Ramón de Osés, Alcalde del Crimen de la Real Audiencia y Juez de Provincia y del Coliseo en turno, enterado el 12 de enero de 1819 de que la Compañía de Cómicos tenía intención de dar funciones en que los actores iban a representar en vestido de mujer y las actrices en el de hombre, ordenó fijar en la puerta del vestuario la providencia en que se mandó que todos los miembros de la Compañía vistiesen el traje de su propio sexo. El Administrador cumplió al pie de la letra con la solicitud de dicho oficial, porque el Escribano vió la copia fijada a la entrada antes de comenzarse la función de esa noche. Pero, empezada la comedia, se supo que, por orden del Alcalde Ordinario de Segundo Voto don Luis Escobar, había sido quitada la copia en cuestión. Se hizo comparecer al gallego Francisco Urbina, Administrador del Coliseo, quien dió su testimonio, confirmando el informe del Alcalde del Crimen. El señor Escobar, en su exposición a la Real Sala, contendió que al otro oficial le faltaba autoridad para hacer poner el cartel en el Teatro "sin vn notorio y violento despojo de la jurisdicción que en el particular egercen los Alcaldes Ordinarios, baxo la inmediata dependencia de la superioridad del Excelentísimo Señor Virrey", " ${ }^{7}$ a quien él, anticipando el nublado que se le venía encima, comunicó al día siguiente lo que había hecho, entregándose asimismo a Su Excelencia la copia del auto desfijado. Agregó el Alcalde Ordinario que su acción no tenía más motivo que defender la jurisdicción de su cargo. En contestación a este punto del señor Escobar, se hizo referencia a la Real Cédula, expedida en Aranjuez, España, el 15 de abril de 1792, en la que se previno que los Alcaldes de la Real Sala del Crimen fuesen por turno semanal a mantener el buen orden en el teatro ${ }^{8}$ y se citaron las declaraciones adicionales del Virrey, decretadas el 17 de marzo del año 1793, que mandaban a los Alcaldes del Crimen asistir a todas las funciones del Coliseo para hacer que el público observase la decencia; que las representaciones de las comedias comenzasen un cuarto de hora después de la oración ${ }^{9}$ (de conformidad con el capítulo $3^{\circ}$ del Reglamento aprobado por Su Majes- 
tad en el año de 1786); ${ }^{10}$ que se pusiese una tabla en el frente extremo del tablado para que no se viesen los pies de las actrices y se eliminase el reflejo de las luces de las candilejas; que se limpiase diariamente el Teatro; que los mozos sólo vendiesen agua durante los intermedios; que aplaudiesen los espectadores con moderación; que las demostraciones que con el nombre de galas ${ }^{11}$ se daban a los actores fuesen moderadas; que los concurrentes no tuviesen puesto el sombrero ni cubierto el rostro; que no se encendiesen hachas de viento; que los hombres no entrasen en la cazuela de las mujeres ni éstas en el lugar de aquéllos, y que los primeros que llegasen ocupașen los asientos, sin preferencia alguna, excepto que las bancas de las lunetas tocasen a las personas con traje más decente. Por decreto del Virrey, de fecha 3 de abril del año 1794, se agregó que los Alcaldes del Crimen debieran prohibir que tirasen al patio desde la cazuela y los palcos yesca encendida, cabos de cigarros, cáscaras de fruta, etc., y que arreglaran que los coches llegasen en filas a la puerta del Coliseo y procediesen libremente en caso de conmociones o riñas entre los cómicos. En oficio del 9 de abril del mismo año se repitió lo dicho referente a lo de cuidar el Teatro, y en orden del día 3 se les concedieron, por otra parte, los auxilios necesarios para la guardia destinada a ese edificio.

El Fiscal del Crimen dió la razón al Alcalde del Crimen, elogiando el celo de éste en vedar la infracción de las leyes que se observaban en los teatros de Madrid y formaban parte de la Novísima Legislación. Con el objeto de defender la acción del Alcalde don Juan Ramón de Osés, el Fiscal pidió que el Escribano de Cámará copiase para él la Real Cédula de 15 de abril de 1792, la que determinó las facultades de los oficiales; pero como no se halló en el Oficio de Cámara menos Antiguo dicha Cédula, se decidió a pedir al Virrey que la hiciese copiar a la mayor brevedad. Cumplióse con esta petición y fué remitida a la Real Sala del Crimen la copia de la citada Real Cédula. Una Real Orden -despachada a Nueva España, en respuesta a una carta de 28 de mayo de 1791 del Regente de la Audiencia- reveló que se le había nombrado a él y a sus sucesores Jueces del Hospital Real de Indios, "ayudándole vno de los Oydores por turno de cada dos años en lo que le encargase". ${ }^{12} \mathrm{E} 1$ Virrey había roto la práctica tradicional, dando separada comisión, sin limitación de tiempo, al que servía de Juez del Coliseo, dividiendo así entre dos oficiales los cargos (Juez del Hospital y el del Coliseo), que habian "estado vnidos más 
de dos siglos desde que se fundó el Coliseo". ${ }^{13}$ Lo que inmutó especialmente al Regente fué la falta de consideración por su puesto de Juez del Hospital, del que era propiedad el Teatro, ${ }^{14}$ inclusive la cuestión de hacer composturas. En el curso de dicho parte, el Regente mencionó también que, a causa de un incendio ocurrido antes, el Coliseo fué trasladado a la Calle de la Acequia, ocupando después un edificio en la Calle del Colegio de las Niñas; que el Virrey Conde de Gálvez formó una sociedad de Directores y Accionistas para el Teatro, la que se disolvió por la pérdida de su dinero; $y$, finalmente, que las funciones de los años anteriores eran mejores que las que se daban entonces. Fué resuelta la cuestión de la autoridad del Regente y de los Alcaldes del Crimen por esta determinación del Rey:

... he resuelto declarar (como por esta mi Real Cédula declaro) que al Regente de esa Audiencia, como Juez del Hospital, de quien es finca el Coliseo de Comedias, sólo compete en éste lo respectivo a obras, reparos y cobro de productos en que se arriende, pudiendo concurrir si quiere, por vía de diversión, al palco que parece tener renovado el mismo Hospital en el lugar que corresponde a su destino. Que el componer las diferencias de los Cómicos, conocer de sus causas por razón de oficio, señalar la hora, cuidar de que las decoraciones sean honestas con lo demás anexo y dependiente corresponde a ese Superior Govierno, $y$, que, mandando vos cesar al Juez del Teatro que havéis elegido, se os prevenga que, a exemplo de Madrid, concurran por turno semanario los Alcaldes del Crimen a efecto de hacer observar con prontitud el buen orden, quietud y sosiego público durante la decoración, 15 entendiéndose que la concurrencia del Regente, si quiere ir al palco, sea en el que según contrata de arrendamiento se hubiese asignado al Hospital $\mathrm{y}$, asimismo, que la concurrencia del Juez del propio Teatro sea del Corregidor y Alcaldes Ordinarios de la Ciudad y no de los Alcaldes del Crimen de esa Audiencia . . .16

El Fiscal del Crimen, creyendo corroborada su opinión con la copia de la citada Real Cédula, sustentó que el Alcalde del Crimen no había hecho más que cumplir con su deber al fijar la orden en la puerta del vestuario. Aludió también a la escandalosa manera en que salieron vestidas las actrices del año anterior "con media, calzón y chaqueta corta". ${ }^{17}$ Añadió éste que, conforme al Reglamento que regía en México, tenían los Alcaldes del Crimen las mismas facultades que los Alcaldes de Corte. Censuró al Alcalde Ordinario por haber 
quitado el cartel sin avisar primero al Juez que lo mandó poner y calificó de violento e irregular su procedimiento. La Real Audiencia acordó que volviese a fijar en el mismo lugar el auto proveído por el Alcalde del Crimen, quien no había usado más que la factiltad que le competió, y que se notificase al Alcalde Ordinario don Luis Escobar para que en lo futuro actuase con más moderación y de una manera menos reprensible. En su informe destinado al Virrey Conde del Venadito, la Real Sala resumió toda la providencia del caso, manteniendo su defensa de la acción del Alcalde del Crimen, citando las facultades tenidas en vigor por los Alcaldes Ordinarios en el Coliseo, pues a ellos "solo les compete la intervención en lo que toca a su govierno económico en la parte corréspondiente a la representación, para que ésta se egecute con el decoro devido como el cuidar de que no haya discordias entre los individuos de la Compañía Cómica; que ninguno falte al cumplimiento de sus respectivas obligaciones sin motivo justo; que los mismos Juezes deverán calificar; que todo esté dispuesto y bien ordenado para la hora en que deve empezar la representación y otras cosas a este tenor". ${ }^{18}$ Como prueba adicional de que el vestuario no podía considerarse exento de carteles, se mencionó que los avisos y edictos se fijaban dentro del palacio del Virrey y en las puertas de las iglesias. Declaróse convencido el Fiscal de que el Alcalde Ordinario no tuvo otro motivo que mostrar que su autoridad era "superior a la de los Ministros de la Sala, exponiendo la de este Tribunal a las murmuraciones de los concurrentes al Coliseo y a la rechifla de los mismos Cómicos". ${ }^{19}$

Fué totalmente contradictoria la opinión del Asesor General, que en substancia sustentó la tesis del Alcalde Ordinario, afirmando que se concedía al Superior Gobierno, por la Real Cédula tantas veces citada, la facultad de mantener el buen orden; que los Alcaldes del Crimen no eran Jueces del Teatro; que el artículo 40 del Reglamento del Virrey Gálvez, que se remontó hasta 1786, dió al Corregidor y a los Alcaldes Ordinarios comisión para que, asistiendo todos los días de comedia, pudiesen sosegar los desórdenes; que la autoridad del Corregidor y de los Alcaldes Ordinarios en el Teatro había sido reconocida durante sesenta y tres años; que el Conde de Revillagigedo, para resolver ciertos problemas ambigtıs, hizo varias declaraciones relativas a los Alcaldes del Crimen, limitando su autoridad en el Coliseo al tiempo que durase la representación y que, como consecuencia de dictar el Señor Osés la providencia de ante- 
mano, violó las reglas; que la Real Sala, sabiendo que el caso había sido elevado al conocimiento de Su Excelencia, no debiera haber declarado "nulo, atentado y escandaloso" el procedimiento del Alcalde Ordinario ni haber hecho refijar el auto en el vestuario, exponiéndose a que sus providencias complicasen las disposiciones del Virrey. Pero todo eso no quería decir que no se oponía a que las actrices mudasen el traje de su sexo. ${ }^{20}$

Los días pasaron, sin despejarse la situación, y así, el 20 de abril, el Virrey Conde del Venadito, asumiendo una actitud conforme con la de su antecesor don José de Iturrigaray, formuló la regla de que los Alcaldes del Crimen ejercieran su autoridad sobre los espectadores, es decir, de telón afuera, y que a los Alcaldes Ordinarios les quedase la obligación de cuidar la conducta de los actores, siendo su jurisdicción de telón adentro y, en consecuencia, teniendo el derecho de imponer la pena de cuatro pesos de multa a los que faltasen a sus obligaciones. También advirtió a los oficiales que no permitiesen que ni los actores ni las actrices cambiasen el traje de su sexo, bajo la pena de veinticinco pesos de multa:

Deviéndose habrir el Teatro esta noche, y no siendo conforme al decoro público ni a la moderación que deve reynar en los espectáculos de vin pueblo ilustrado las hojas y visiones y particularidades que se han observado los vltimos días en el Coliseo de esta Capital, ni deviendo sufrirse la demasía con que, por aquella razón, se ha producido alguno de la Compañía a las fas del público y de los Magistrados, prevalido de la inprudencia de ciertas personas poco refreceivas (sic), he resuelto que, de oy en adelante, se observe en el Teatro la mayor circunspección y orden absteniéndose todos y cada vno de los espectadores de silvar, sesear y mofarse en manera alguna de los actores y actrices, en el concepto de que contra qualquiera se tomará la providencia más conveniente y executiva por el Señor Alcalde de Crimen, de que él encargó según su jurisdicción, y a los Señores Jueces políticos y militares, que exercen su autoridad en el Coliseo, prevengo que, para no dar ocasión a la mortificación del público, quedan los Señores Alcaldes que estén en turno y a quien compete de que los actores desempeñen sus papeles excactísimamente y cumplan con las obligaciones a que se han constituido, imponiendo al que faltare a ellas y a la desencia de la excena la pena de 4 pesos de multa, como igualmente al Cómico o Cómica que por pretexto alguno se desmande en la acción con palabras injuriosas a los expectadores, pues será castigado además con la pena de 4 pesos a que se ha hecho acredor, sin que le sirva dé excusa la 
inprudencia de algunos de los concurrentes... Además estarán a la mira dichos Señores Alcaldes para que ni los actores se vistan de mugeres ni éstas de hombres, bajo la pena de 25 pesos de multa, dándome parte cada vno de los Señores Jueces nombrados de su caso o jurisdicción de quanto ocurre digno de mi consideración y de las providencias ejecutivas que hayan tomado durante la representación, para determinar lo que sea justo como Juez privativo del Teatro con arreglo a las soberanas disposiciones de la materia. 21

\section{EXPEDIENTE}

Superior Govierno

Año de 1819

\section{Quaderno 3.०}

Testimonio del Expediente formado sobre que no se permita en el Coliseo mudar a las actrices en las funciones el trage propio de su sexo en el de hombres ni a éstos en el de ellas.

Oficio más Antiguo.

1f. Auto del)

Sr. Osés )

$1 v$.

Notificación)

al Asentista)
En la Ciudad de México, a doce de enero de mil ochocientos diez y nueve, el Señor Don Juan Ramón de Osés, del Consejo de Su Majestad, Alcalde del Crimen de esta Real Audiencia, Juez de Provincia y del Coliceo en turno, etcétera, dixo: que, teniendo noticia de que a beneficio de algunos individuos de la Compañía Cómica, van a egecutarse funciones en que está dispuesto que los hombres salgan en trage de mugeres $y$ las mugeres en trage de hombres; $y$, siendo esto contratio a las buenas costumbres $e$ injurioso al público, porque se ofende el pudor, la decencia y el decoro, manda que por ningún motivo los Actores y Actrices ni otro individuo de dicha Compañia muden de trage, sino que cada vno vista el suyo propio baxo las penas a que haya lugar en caso de contravención, haciéndose saber esta providencia al Asentista y fixándose vna copia de ella en el vestuario, para que llegue a noticia de todas las personas a quienes toca su cumplimiento $y$ ninguna pueda alegar ignorancia. $Y$, así, por / éste su auto lo mandó y firmó Su Señotía. De que doy fe. Osés. José Andrade. 1

En el mismo día, yo el Escrivano, siendo presente el Asentista Don José María Landa, en su persona que conosco, le hize saber lo determinado en el auto que antecede; $y$, entendido, dixo lo oye y está pronto a no permitir las funciones que se anuncian en los términos que se expresan. Esto respondió y firmó. Landa. José Andrade. 
Diligencia)

Certificación)

$2 f$.

Decreto)

Razón)

Declaración )

del Asentista)

$2 v$.
En la tarde del mismo día, en puntual cumplimiento de lo mandado, pasé al Coliseo a hacer fixar la copia que se previene en el auto del Señor Juez, la que por haverme expresado el Administrador que si en aquella hora se fixaba, como que aquello estaba todavía solo, podía cualquiera quitarla; se la entregué, para que lo veríficase luego que llegase el Portero $y$, haviendo, antes de comensarse la comedia en la noche, entrado adentro del Teatro a ver si havía fixado dicha copia, me encontré con ella fixada a la entrada, junto a la luz que se pone, en disposición de que ninguno podia dexar de verla. $Y$, para que conste, lo siento por diligencia. Doy fe. Andrade.

Certifico y doy fe que la noche del dia de ayer, luego que se acabó la comedia, haviendo entrado de orden del Señor Juez de este expediente al Teatro a ver si aun continuaba fixada la copia que se expre-/ sa en la anterior razón, me encontré con ella quitada, y según se me informó por el Administrador $y$ algunos individuos de alli, se quitó de orden del Alcalde Ordinario, que está en turno, por el Escrivano de su Asistencia. Y para que conste, de mandato verbal de Su Señoría, pongo la presente en la Ciudad de México, a trece de enero de mil ochocientos diez y nueve. José Andrade.

México, trece de enero de mil ochocientos diez y nueve. $V$ istas las anteriores diligencias, dése cuenta a la Real Sala con el correspondiente informe. Lo proveyó el Señor $J_{\text {nez }}$ y lo firmó. De que doy fe. Osés. José Andrade.

En el mismo día se agregó el oficio puesto por el Señor Juez a Su Alteza la Real Sala, y, para que conste, pongo esta razón. Andrade.

En el mismo día compareció ante Su Señoria Don Francisco Vrbina, Administrador del Coliseo, quien, baxo la sagrada religión del juramento, asentó ser español, originatio del reino de Galicia, soltero, de treinta y ocho años, y preguntado con arreglo a los particu-/ lares de este expediente, dixo: que ayer, poco antes de las oraciones de la noche, por encargo del presente Escrivano, fixó por su misma mano vna copia que le entregó de la providencia, para que los Actores y Actrices ni otro individuo de la Compañía Cómica muden de trage; y la dexó al cuidado del Portero a la entrada del Teatro o vestuario. junto a la luz de la puerta; mientras el que declara se ocupaba en los negocios de su cargo, y haviendo buelto al mismo. sitio después que empesó la función, advirtió que ya no estaba alli aquel papel $y$, recombiniendo al Portero. le respondió éste que lo havía quitado el Escrivano de la 
Oficio)

$3 f$.

$3 v$.

Decreto)

Declaración )

del Escriva- )

no Zamorano)
Asistencia del Alcalde Ordinario de Segundo Voto, a cuyo tiempo entró el mismo Escrivano y aquietó al que declara, asegurándole que él to havia quitado de orden del citado Alcalde, que es quanto tiene que declarar y la verdad por el juramento que ha prestado en que se ratificó y firmó con el Señor Juez. Doi fe. Osés. Francisco Vrbina, José Andrade.

Mui Poderoso Señor. Por las razones que expresa mi providencia de ayer, mandé en ella, como Juez del Coliceo en turno, que los Actores y Actrices ni otro individuo de la Compañía Cómica muden de trage, sino que cada vno vista el suyo propio y que se hiciese saber así al/Asentista, fixándose vna copia de la misma providencia en el vestuario, para que por este medio llegase a noticia de todas las personas a quienes toca su cumplimiento y ninguna pudiese alegar ignorancia, al mismo tiempo que se evitava el incombeniente de hacerse público vn tal desorden, si se hubiera fixado a la entrada del Coliceo. Notificado el Asentista, se cumplió también con la segunda parte de mi providencia, haviéndose fixado dentro del foro en parte donde podía ser vista por los individuos de la Compañia Cómica, pero, antes de concluirse la función de anoche, se quitó de orden del Alcalde Ordinario de Segundo Voto por el Escrivano de su Asistencia, según así consta por la [s] diligencias puestas por el Escrivano Andrade, Receptor de esta Real Sala. Todo lo qual elevo a la superior noticia de Vuestra Alteza, con el expediente original, para que determine lo que sea de su agrado. Dios guarde a Vuestra Alteza muchos años. Mé- / xico, trece de enero de mil ochocientos diez y nueve. Mui Poderoso Señor. Juan Ramón Osés. Señores Governador y Alcaldes del Crimen de la Real Sala.

México, enero, trece de mil ochocientos diez y nueve. Recivase la justificación del hecho en el día y dése cuenta y lo rubricaron. Aquí cinco rúbricas.

En seguida se hizo comparecer al Escrivano Don Félix Fernando de Zamorano, quien, baxo la sagrada religión del juramento, of reció decir verdad en quanto se le preguntara $y$, siéndolo con arreglo a la cita que le hace el anterior testigo, Don Francisco Vrbina, dixo ser positiva la cita, añadiendo que empesada la representación de anoche, le dixo el Señor Alcalde Ordinario Don Luis Escovar, que qué contenía el papel que estaba fixado en el Teatro y, respondiéndole que [era] copia de vn auto proveido por el Señor Osés, prohiviendo que los hombres se vistiesen de mugetes y las mugeres de hombres, diciéndole 
$4 f$.

Decreto)

Notificación)

Ynforme del , )

Alcalde Ordinario)

$4 v$. al mismo tiempo el mismo Señor Alcalde que se lo llevase, que si combiniera a otro dia, se volvería a poner y que. cumpliendo el que declara con esta orden, lo quitó del lugar donde se hallaba y se / lo entregó, quedándose dicho Alcalde con él: que es quanto tiene que decir y la verdad en que se ratificó y firmó con Su Señoría. Doy fe. Osés. Félix Fernando Samorano. José Andrade.

México, enero, trece de mil ochocientos diez y nueve. Ynforme el Alcalde Ordinario de Segundo Voto para primera audiencia sobre el hecho de este expediente y motivo que tubo para egecutarlo y lo rubricaron. Aquí cinco rúbricas. José Andrade.

En el mismo día yo, el Escrivano de Cámara, pasé al Juzgado del Caballero Alcalde Ordinario de Segunda Elección $y$, estando presente, le instruí de lo proveído en el superior auto que antecede, quedando en su poder el expediente. De que doy fe. Escovar. Francisco Calderón.

Mui Poderoso Señor. Como Juez en turno del Teatro, me dió, antes de anoche, parte mi Escrivano de que en el vestuario se hallaba fixada la copia del auto del Señor Don Juan Ramón/de Osés sobre que trata este expediente. Al mismo tiempo se me convenció por quantos alli estaban de que aquella determinación no tocaba a la autoridad del Señor Alcalde de Corte, ni podía mandarla fixar en dicho Iugar sin vn notorio y violento despojo de la jurisdicción que en el particular egercen los Alcaldes Ordinarios, baxo la inmediata dependencia de la superioridad del Excelentísimo Señor Virrey, a quien corresponde el conocimiento en la materia. Por este concepto, para certificarme más en él y con el objeto de procurar el acierto en mi resolución, mandé al. Escrivano que desfixase la copia del auto, asegurando públicamente que si era justo se volvería a poner inmediatamente; pero en virtud de los sólidos fundamentos que demuestran ser privativa la jurisdicción de los Alcaldes Ordinarios en la materia y mediante la quieta, pacífica poseción de ella, en que existen y los han mantenido 'siempre repetidas resoluciones del Superior Govierno, sin que se haya permitido jamás exemplar alguno como el presente, de que yo me haría responsable; me pareció preciso comunicarlo todo al Excelentísimo Senor Virrey, como lo hize el día de ayer, elevando a su superior / conocimiento esta ocurrencia, exponiendo los méritos que apoyan mi jurisdicción y acompañándole la copia del auto que se desfixó, para que, en vista de todo, se sirva Su Excelencia determinar lo que fuere de su justificado agrado. Es quanto devo informar a Vuestra Alteza, 
Oficio)

$5 \mathrm{v}$

Auto)

Razón)

Papel exivido por) el Señor Ministro) Medina

$6 \mathrm{f}$. en cumplimiento de su superior auto del día de ayer, protextando que por mi parte, no ha havido más interés sino el de la defensa que he creído necesaria de la jurisdicción de mi cargo, estando mui distante por genio y por convencimiento de succitar ( $\mathrm{sic}$ ) competencias indevidas, y $\mathrm{mu}$ cho más de faltar voluntariamente en nada de quanto sea devido al exacto cumplimiento de mis obligaciones. México, enero catorce de mil ochocientos diez y nueve. Mui Poderoso Señor. Luis Escovar. 2

Mui Poderoso Señor. Con el informe que Vuestra Alteza se sirvió prevenirme en su superior auto del día de ayer, debuelvo el expediente instruido con ocación de la providencia dictada por / el Señor Don Juan Ramón de Osés sobre que los Actores del Coliceo de esta Capital no muden de trage como tenían proyectado en varias funciones. Dios guarde a Vuestra Alteza muços años. México, enero catorce de mil ochocientos diez y rueve. Mui Poderoso Señor. Luis de Escobar. A los Señores Governador y Alcaldes de la Real Sala del Crimen de esta Real Audiencia.

México, catorce de enero de mil ochocientos diez y nueve. Visto, agréguense los antecedentes y pase de preferencia a la vista del Señor Fiscal y lo rubricaron. Cinco rúbricas. Francisco Calderón.

No existen en el Oficio de Cámara de mi cargo ningunos antecedentes relativos al asunto de que se trata, por lo que sólo se agrega el testimonio del papel exivido por el Señor Ministro Don Yldefonzo José de Medina, según me ha prevenido la Real Sala. México, catorce de enero de mil ochocientos diez y nueve. Calderón.

Jurisdicción y autoridad de los Señores Alcaldes del Crimen en el Coliseo de esta capital. Por Real Cédula fecha en Aranjuez, de quince de abril de mil setecientos noventa y dos, previene Su Magestad que, cesando el Juez del Teatro que anteriormente se nom-/braba, concurran por turno semanario, a exemplo de Madrid, los Señores Alcaldes de esta Real Sala del Crimen, a efecto de hacer observar el buen orden, quietud y sosiego público. Consultadas al Excelentisimo Señor Virrey por la Real Sala las dudas que se of recieron, para que allanados los embarazos que pudiesen ocurrir, que se evitasen disputas y competencias que ocasionasen inquietudes y dar la devida inteligencia y discución a la citada Real Cédula por decreto de diez y siete de marzo próximo pasado, se sirvió $\mathrm{Su}$ Excelencia hacer las declaraciones siguientes: Que a los Señores Alcaldes del Crimen, que por turno deven asistir a todas las diversiones que ocurran en el Coliseo, les co- 
$6 \mathrm{v}$.

rresponde cuidar de la observancia de quanto concierne a la seguridad, decensia y buen orden del público, como es el que se comience la comedia vn quarto de hora después de la oración, conforme al capítulo tercero del Reglamento que se formó en el año de mil setecientos ochenta y seis, y tiene aprobado Su Magestad. Que el extremo/ del tablado, por de frente en toda su latitud, se conserve la tabla que se haya puesto con el fin de que no se $v[\mathrm{e}]$ an los pies de las Actrices y se impida el reflexo de las luces de las candilejas. Que se asee diariamente el patio, los palcos, luneta y demás partes del Teatro para que esté con la devida decensia. Que los mozos que venden aguas lo hagan sin gritar y sólo en los intermedios de la representación, dexándose ver por los costados de las bancas o entrando por los claros de ellas. Que no haya estrépito que se haga molesto al concurso, aunque no se privará a los expectadores el que con moderación y decoro manifiesten su gusto y satisfacción y aplaudan alguna pieza bien egecutada, pero, en el caso de que alguno de los concurrentes dé voces descompuestas o haga otra demostración que perturbe a los Actores o incomode a los expectadores, se castigatá conforme a su exceso y las circunstancias del delincuente. Que las demostraciones, que con el nombre de galas suele hacer el público a algún Actor con el objeto de que este aliciente le estimule al mayor esmero en el cum plimiento de su obligación, sean moderadas y prudentes, sin profusión ni prodigalidad, / pues de lo contrario se prohivirán enteramente que desde que empieza la representación hasta que se concluya en sus respectivos actos, ninguno de los concu $[\mathrm{r}$ ] rentes tenga puesto el sombrero, ya sea en las lunetas, bancas o demás parages, para que no se impida la vista a los que están detrás. Que no se enciendan achas de viento, de puertas adentro de la casa de teatro, para evitar el riesgo de vn incendio. Que en las puertas, portales, tránsitos de los patios y escaleras no se permita por las centinelas que nadie tenga cubierto el rostto ni esté de modo que estorbe la franca entrada y salida. Que ningún hombre suba a la casuela de las mugeres ni éstas a la de los hombres. Que en las bancas, palcos y mosquetes, que se alquilan por asientos, no haya preferencia, sino que los tomen los primeros que lleguen, sin que sirva de pretexto que el Acomodador diga están ya tomados, pero las bancas de las lunetas, como rno de los sitios más distinguidos y señalados, deven estar ocupadas 3 por las personas que concurran con trage más decente, por decoro de las mismas personas y por el devido al público. Y, últimamen- 
7v.

te, que los concurrentes no pidan con imprudencia la repetición de bailes, tonadillas y otras piezas o que salga algún Actor a egecutar algunas de estas havilidades, pero bien se permitirá a los con-/ currentes el que pidan la repetición de alguna de estas piezas, con tal de que lo hagan con la moderación devida, y estando entendidos de que si por algún justo motivo no se les concediese, no se ha de instar a ello. Y para que el público no pueda alegar ignorancia de estas disposiciones en la parte que le comprehende, se fixarán en los parages más proporcionados del mis mo Teatro vnos avisos que lo hagan saber a todos los concurrentes. Por oficio del Excelentísimo Señor Virtey, de tres de abril de este año, que se halla agregado al expediente, se sirvió $S u$ Excelencia añadit a las anteriores declaraciones las siguientes: Que, siendo tan general el vso del tabaco de humo en esta Capital, no es fácil impedirlo en el Coliseo, pero sí deve prohivirse el que los concurrentes arrogen desde la casuela y palcos yezca encendida y cabos de cigarros al patio, sucediendo no pocas veces que se quemen los vestidos y capas de las personas que ocupan los palcos más baxos, bancas y mosquete. Que deve impedirse iqualmente que escupan al patio, tiren cáscaras de $8 f$. fruta, cabos de velas y otras [cosas] / con que incomodan al concurso, manchan la ropa y se succitan algunas riñas. Que toca el cuidado de esto y otras cosas semejantes al Senor Alcalde del Crimen y hacerlo saber al público por medio de impresos, como tengo dispuesto en la citada declaración. Que, asimismo ha de hacer observar el que los coches lleguen en orden y en filas a la puerta del Coliseo, para que los tomen los dueños conforme ocurran, sin que permanescan parados en la calle principal ni se atropellen vnos a otros para llegar con anticipación, continuando por el mismo orden que se ha practicado en todo el tiempo de mi govierno, con ecepción de los propios de los Señores Jueces. ${ }^{4} \mathrm{Y}$, succitada la duda de si ocurriendo riñas escandalošas, golpes o heridas o conmoción entre todos o la mayor parte de los Cómicos, se devería dexar proceder libremente al Señor Alcalde de Corte por estos excesos como turbativos del buen orden, como se consultó a Su Excelencia. $Y$, en oficio de nueve de abril, se sirvió declarar la duda en los términos siguientes: Que los expresados Señores Ministros, durante la representación, tengan conocimiento de las disputas criminales que puedan of recerse en el Coliseo, siendo perturbativas al buen orden, quietud y sosiego público dentro y fuera del vestuario. Que, para el efectivo cum-/ plimiento de lo prevenido en orden de 
9 f.

Dictamen del St.) Fiscal del Crimen) tres del corriente, por lo respectivo: a la que han de guardar los coches, se permita la de que se dé a los citados Señores Ministros los auxilios necesarios por la guardia destinada a la Casa de Comedias. Vltimamente, que pueda asistir con los Señores Alcaldes vn Receptor de la Real Sala para las prontas diligencias que se of rescan, sin perjuicio del Escrivano del Coliseo, Don Mariano Zepeda, que deve continuar sin novedad en la propia forma que hasta aqui, actuando éstos dos los asuntos y negocios del Teatro que necesiten esta formalidad. México, y abril catorce de mil setecientos noventa y quatro. Rafael Lucero. Concuerda con su original que existe en el Archivo del Oficio de Cámara más Antiguo, que es a mi cargo, a que me remito, hallándose firmado, según se advierte, por Don Rafael Lucero, Escrivano de Cámara, que también fué del citado Oficio. Y de orden verbal de la Real Sala saqué el presente. en México, a catorce de enero de mil ocho-/ cientos diez y nueve. Doy fé. Francisco Calderón.

Mui Poderoso Señor. El Fiscal del Crimen dice: que es mui justo y conforme a las leyes que se eviten los pecados públicos, y a todos los juezes y justicias se les impone por ellas tal obligación, siendo, como nadie duda, vno de tantos que las personas que representan en los teatros cambien los trages de su sexo, y estando por lo mismo vedado ese vso detestable y ofensivo al decoro de las constumbres por el Reglamento que se dictó para el buen otden dél de esta Capital, en el que se reprodugeron las antiguas prohiviciones del punto contenidas en los que goviernan los Coliseos de Madrid y hoy forman parte de la Novísima Legislación. Es por lo mismo loable el celo de vuestro Alcalde Don Juan Ramón Osés, que previno, por el auto sobre que gira este expediente, la escandalosa infracción de $\tan$ morales disposiciones, que ya se preparaba en su desprecio, y aunque hoy se le disputan las facultades con que lo hizo, subsistiendo su providencia, no deven prevalecer los interesados en tan raro expectáculo de lo pendiente de la decisión, y en caso de querer hacerlo y que llegue a noticia de este Superior Tribunal, pide el Fiscal a Vuestra / Alteza, en cumplimiento de la Ley veinte y nueve, título diez y ocho, libro dos de las Yndias, 5 que se tome la determinación que corresponda para el escarmiento devido y respecto de las autoridades. Para que pueda pedir lo combeniente en el punto que ahora succita el Alcalde Ordinario, es preciso que tenga a la vista la Real Cédula de quince de abril de mil setecientos noventa y dos que, como observa nuestro Conde de Revillagigedo 
10f. Decreto)

Razón)

Otra )

Minuta)

$10 \mathrm{v}$

Réeal Orden) en la instrucción que dejó a su succesor Marqués dẹ Branciforte, ${ }^{6}$ es la que previno la asistencia al Teatro de los Alcaldes de esta Real Sala y la que determinó sus facultades. Por lo qual Vuestra Alteza ha de servirse mandar que se agregue el correspondiente testimonio por el Escrivano de Cámara, en cuyo Oficio exista. pues se comunicó, y que con él buelva el expediente a la vista del que responde. México, quince de enero de mil ochocientos diez y nueve. Berasueta.

México, enero quince de mil ochocientos / diez y nueve. No existiendo en el Oficio de Cámara menos Antiguo la Real Cédula [a] que se tefiere, pásese al Excelentísimo Señor Virrey el cortespondiente oficio, a fin de que se sirva remitir copia de ella y lo rubricaron. Cínco rúbricas. Francisco Calderón.

Con respecto a que todos los asuntos de acuerdo pertenecen 7 al Oficio de Cámara más Antiguo, siendo de esta naturaleza el de la Real Cédula, de que se trata en este expediente, no puede ni deve existit en este Oficio menos Antiguo de mi cargo; y aunque por vna casualidad pudiera haberse pasado a él, en el reconocimiento de causas que se ha estado haciendo para la formalización del Ynventario de este Oficio, se hubiera encontrado. Para su constancia pongo esta razón en diez y seis del corriente enero. Doy fe. Cartami.

Fecho en el mismo día el oficio prevenido cuya minuta se agrega. Vna rúbrica. De resultas del absoluto trastorno 8 que han sufrido los Archivos de los Oficios de Cámara de esta Real Sala desde la Constitución, no se encuentra ${ }^{9}$ en ellos la Real Cédula de quince de abril de mil setecientos noventa y dos, relativa a la asistencia de los Señores Alcaldes del Crimen al Teatro de esta Capital y su jurisdicción. $Y$, necesitándose, tenerla a la vista, ha acordado el Tribunal dirigir a Vuexcelencia al presente a fin / de que se sirva disponer que por su Secretaría de Cámara se saque vna copia de ella a la mayor posible brevedad. Dios \&a. Enero catorce de mil ochocientos diez y nueve. Excelentísimo Señor Virrey.

El Rey. Virrey, Governador y Capitán general de las Provincias de la Nueva España y Presidente de mi Real Audiencia que reside en la Ciudad de México. En carta de veinte y ocho de mayo del año próximo pasado, dió cuenta con testimonio y vna certificación el Regente de esa Audiencia Don Francisco Xavier de Gamboa, de que, aunque fué obedecida por vos y esa Audiencia la respectiva Real Cédula de veinte y vno de septiembre del propio año, que se os dirigió y en que se le nombró y a sus succesores 
$11 \mathrm{f}$.

$11 \mathrm{v}$.

en dicho empleo por Juezes del Hospital Real de Yndios de esa Capital, ayudándole 10 vno de los Oydores por turno de cada dos años en lo que le encargase, se havían disminuido las facultades que eran propias de los Jueces en turno de cada dos años del mismo Hospital, conforme a la ley mediante a que vos, antes de haberse recivido la referida Real Cédula, ha- / víais acordado 11 el turno, continuando para aquel año por Juez del Hospital al Oidor Don Cosme de Mier, que lo havía sido en el antétior inmediato y dádole separada comición, sin limitación de tiempo, para Juez del Coliseo; ${ }^{12}$ pues, aunque presentó su real nombramiento, cesó en el Hospital y no en el Coliseo por la especial comición que le disteis, sin que alcansase la razón por qué haciais aquella novedad quando era. mi real voluntad que egersiese vno y otro encargo, respecto de haber estado vnidos más de dos siglos desde que se fundó el Coliseo; pues, quando por su incendio se separó a la Calle de la Acequia y después a la del Colegio de las Niñas, como finca propia del Hospital, a cuyas expensas se hicieron los $\mathrm{r}[\mathrm{e}]$ edificios $\mathrm{y}$ composturas, según era público y consta 13 a los Ministros de este Consejo que sirvieron en esa Audiencia y egercieron simultáneamente su mando en el Hospital y Coliseo por el turno que prescribía la ley, a causa de no poder los Virreyes egerser este encargo por el peso de otros gravísimos en que egercitaban su autoridad, añadiendo que, aunque vuestro antecesor, el Conde de Galves, formó vna Sociedad de Directores y Accionistas para el Teatro, se disociaron luego con pérdida de su dinero y volvió a reunirse como siempre havía estado al Oidor/en turno Don Eusebio Bentura de Beleña, y por igual turno a Don Cosme de Mier, no sólo por vno, sino por dos años, cortándose el turno practicado en todos tiempos, y que devió cesar por el nombramiento que de propio motu tube a bien hacer en los Regentes, los quales podrían egecutar el todo o encargar al Oidor en turno. bienal lo que les pareciese oportuno, supuesto que en ningún tímpo havían podido los Virreyes dedicarse al cuidado del Hospital y Coliseo y, por lo mismo, previno la ley el turno anual de los Oidores, que invariablemente se havía observado; y siendo mi real voluntad que cesase. este turno y recayera todo en los Regentes, se havía truncado la autoridad, queriendo que subsistiese [i] limitadamente el referido Oidor Don Cosme de Miér en el Coliseo con. el palco que siempre havian tenido los Oidores de turno del Hospital, con la monstruosidad de que, teniéndole el Mayordomo de él como tal, no se le havía dado al Re- / gente, siendo él Juez, ni tampoco lo havía pedido, porque 
nunca havía visto comedia desde que pasó a servir en esa Audiencia y, sin duda hubiera encargado el arreglo del Coliseo al Oidor en turno bienal, como lo ofreció hacer dicho Oidor Don Cosme de Mier dentro de esa Audiencia y a presencia de todos los Ministros; pero mui luego quiso introducirse a mandar hacer vna compostura en la Casa de Teatro, avisándole que vos la haviais mandado pagar, bien que inmediatamente conocisteis tocarle como Juez del Hospital, dueño de la finca, que sabría economisar en su aliño y composturas y más en tiempo en que el año anterior se extinguieton seis mil pesos de vn capital de capellanía para composturas del Teatro, recargándose los trescientos pesos anuales de réditos al Hospital, como os lo representó, lo qual no fué suficiente para que le dexaseis egerser su autoridad en el Teatro ni delegarla al Oidor en turno bienal, sino que llevasteis adelante la comición ilimitada que disteis al referico Oidor con novedad y alteración nunca vista; pues si en más de dos siglos los Oidores en turno anual havian corrido con todo lo mismo que el Oidor Mier hacía por la comición ilimitada, haría por su nombramiento y encargo en el bienio y lo mismo los

$12 \mathrm{v}$. succesores en turno, como se/verificó en los anteriores tiempos en que se hicieron funciones solemnes en el Teatro, así por los Impresarios como por los Mayordomos del Hospital, y mejores que las que actualmente se hacían, y concluyó el Regente diciendo que al primer oficio que os pasó le contextasteis, insistiendo en que en comición devía prevalecer, a que os satisfizo hallarse pronto a obedeceros y darme cuenta para que me sirviera explicar mi real mente de que él no tenía duda; pero, después, por dos oficios que le pasasteis se vió precisado a manifestaros lo que constaba en otros dos suyos, insertos en el testimonio que incluya, y de la certificación separada del Escrivano del Real Hospital y Coliseo, que también acompañaba, del corto tiempo que duró el proyecto de buestro antecesor el Conde de Gálvez, y de la reunión posterior en los expresados Oidores, Don Eusebio Ventura de Beleña y Don Cosme de Mier, del encargo del mismo Hospital con el Coliseo, pues, sin embargo de que os amaba con la ma$13 f$. yor atención por haber recivido de vos especiales / fabores; y, asimismo de buestros padres y familia, ya que yo le havía nombrado por Juez del enunciado Hospita[1] y quanto le pertenecía, se veía en la obligación de indemnizar las facultades que le competían: para que sus succesores en la regencia no le imputasen omición, me lo hacía presente, a fin de que como dueño y soberano me sirviera resolver acerca del particular lo que fuera más de mi real 
av. agrado. Visto en mi Consejo de Yndias con la que en su inteligencia y de los antecedentes expuso mi Fiscal $y$, consultándome sobre ello en treinta y vno de enero de este. año, he resuelto declarar (como por esta mi Real Cédula declaro) que al Regente de esa Audiencia, como Juez del Hospital, de quien es finca el Coliseo de Comedias, sólo compete en éste lo respectivo a obras, reparos y cobro de productos en que se arriende, pudiendo concurrir si quiere, por vía de diversión, al palco que parece tener renovado ${ }^{14}$ el mismo Hospital en el lugar que corresponde a su destino. Que el componer las diferencias de los Cómicos, conocer de sus causas por razón de oficio, / señalar la hora, cuidar de que las decoraciones sean honestas con lo demás anexo y dependiente corresponde a ese Superior Govierno, y, que, mandando vos cesar al Juez del Teatro que havéis elegido, se os prevenga que, a exemplo de Madrid, concurran por turno semanario los Alcaldes del Crimen a efecto de hacer observar con prontitud el buen orden, quietud y sosiego público durante la decoración, entendiéndose que la concurrencia del Regente, si quiere ir al palco, sea en el que según contrata de arrendamiento se hubiese asignado al Hospital y, asimismo, que la concurrencia del Juez del propio Teatro sea del Cortegidor y Alcaldes Ordinarios de la Ciudad y no de los Alcaldes del Crimen de esa Audiencia; lo que os participo pata buestra inteligencia y govierno a fin de que como os lo ordeno $y$ mando cumpláis y hagáis cumplir y egecutar puntual y efectivamente la expresada mi real resolución, en inteligencia de que con fecha de este día se comunica también al propio efecto al nominado Regente, a la Sala del Crimen de esa Audiencia y al Corregidor y Alcaldes Otdinarios de esa Capital por ser así mi voluntad, fecha en Aranjuez, a quince de abril de mil setecientos noventa y dos. Yo el Rey. Por mandado del Rey, Nuestro Señor. Antonio Bentu-/ ra de Taranco. Es copia. ${ }^{15}$ México, diez y seis de enero de mil ochocientos diez y nueve. Humana.

Anuente con lo que Vcías. me dicen en su oficio del día de ayer, les remito la adjunta copia certificada de la Real Orden de quince de abril de mil setecientos noventa y dos sobre la asistencia al Teatro de esta Capital de los Señores Alcaldes de Cotte y de las facultades que en ella se les ha concedido. Dios guarde a Vcías. muchos años. México, diez y seis de enero de mil ochocientos diez $y$ nueve. E1 Conde del Venadito. Señores Gobernador y Alcaldes de la Real Sala del Crimen.

México, veinte de enero de mil ochocientos diez y nueve. Agréguese a su expediente y pase a la vista del Señor 
Fiscal y 10 rubricaron. Cinco rúbricas. Mui Poderoso Señor. El Fiscal del Crimen dice que, según el literal tenor del Reglamento dictado para el govierno del Teatro de esta Capital, corresponde a los Señores Alcaldes del Crimen cuidar de todo lo que sea concerniente a la decencia, buen orden y sosiego público y que, como perteneciente a estos ramos, se les encarga entre otras cosas que se mantenga: en el tablado la cornisa que impide se les vean los pies a $14 \mathrm{v}$. las Cómicas, porque setía ofensi- / vo del pudor y de la: honestidad. Supuestas estas facultades y las demás que inconcusamente les tocan para evitar los escándalos públicos en qualquier parte que se cometan; nada tiene de extraño que vuestro Alcalde Don Juan Ramón Osés hubiera dictado, quando estubo de turno, el auto con que da principio este expediente dirigido a impedir que mudasen las: Actrices los trages de su sexo y que se vistiesen el de hombres como lo han egecutado otras vezes, no siéndolo tampoco que mandase fixarlo en vn parage donde pudiesen verlo los sugetos a quienes pertenecía su cumplimiento y observancia. En la Real Cédula de quince de abril de mil setecientos noventa y dos, agregada a pedimento de este ministerio, se previno que asistiesen al Teatro Alcaldes del Crimen, como lo hacían los de la Sala de Madrid, para que cuidasen en la manera que aquellos Magistrados de el orden y sosiego público, y en el Reglamento, que se extendió para su mayor explicación, se explanaron las facultades que les correspondían y aun se les hizo vna delegación expresa de las pertenecientes al Superior Govierno, como se advierte desde luego en los artículos que declaran. la hora en que deve empesar el expectáculo y el conocimiento que ban de tomar en las querellas y disenciones de los Cómicos, aunque suce- / dan en el mismo vestuario. $\mathrm{Si}$, como algunos quieren, se limitase su poder a mantener solamente el sosiego, sin tomar providencia en los excesos de los Cómicos, trascendentales hasta el público, iqué indecoroso no sería el estado de su jurisdicción, impotente para corregir las faltas en la honestidad del vestido, en lo lascivo de los ademanes y gestos en las adicciones livertinas a la letra de las comedias y en otras muchas cosas que ultrajarian no menos su representación que las costumbres! ¿Y cómo se ha de persuadir que con tal limitación se expusiese a los Magístrados, en caso de alguna negligencia o descuido, a presenciar esos desórdenes, sin poder sugetarlos sólo porque en aquel lugar no tenían las facultades que en todos los públicos les concede la ley. sin embargo de presidir la concurrencía?. Sería semejante disposición vn absurdo, de que estubieron / mui lexos: 
$16 f$.

los dignos autores del Reglamento y de la Cédula, y sería también cosa mui rara que, poniendo a su cuidado que se mantubiese la madeta que impide ver los pies de las actrizes, no lo estubiera que saliesen vestidas con medias, calzón y chaqueta corta, de modo que no dexasen que dudar a los expectadores de lo regular o desproporcionado de sus formas. Vuestra Alteza se halla instruido de que así se ha representado en funciones egecutadas en el año pró ximo, y su justificación llevaría a mal en este punto la negligencia de los Ministros que asisten al Teatro bastantemente autorizados, como merecería tal descuido el soberano desagrado, si llegase la noticia de él hasta el trono. Los Señores Alcaldes de la Corte, a cuyo exemplo se ordenó la asistencia de los del Crimen, tienen las mismas facultades, como se deduce de las Leyes diez y once, título treinta y tres, libro siete de la Recopilación Novísima, de donde está tomado el Reglamento que rige en esta Capital. En el artículo veinte de la primera ${ }^{16}$ se prohive que las mugeres representen vestidas de hombres y en el veinte y tres se encarga a esos $\mathrm{Mi}$ - / nistros que emplen (sic) todo su cuidado en la observancia de lo referido, como tan importante al servicio de ambas Magestades. 17 Lo económico de los teatros de Madrid siempre estubo encargado a otras manos, sin que por eso se reputasen impedidos los Alcaldes de Corte para disponer lo necesario a la decencia, buen orden y sosiego; y nadie, ciertamente, se atreverá a decir que lo están los del Crimen, si lè [e] con reflexión las disposiciones que goviernan en el asunto y medita los graves inconvenientes que se seguirian de contrario. Supuesto eso, eta mui regular que, tratándose de impedir vn escándalo, se hiciera saber la prohivición a los que podian infringirla, y ningún medio más a propósito al efecto que fixar vna copia del auto en el sitio en que se hizo y al que por precisión habian de ocurrir todos los Cómicos. Este hecho en nada vsurpa la jurisdicción del Alcalde Ordinario, pues

$16 \mathrm{v}$. aun quando la tenga (en / cuya discución no necesita entrar el Fiscal) no es exclusiva de la autoridad que preside en el Coliseo y que, como se ha manifestado, es la del Ministro del Crimen, especialmente quando en este punto se ha notado el descuido que nadie ignora y que prueva la celebración de muchas representaciones en que se ha cometido ese exeso que llamó finalmente la atención de otros Magistrados. Pero, aun quando la vsurpase tal procedimiento, el Alcalde Ordinario devió haberse abstenido de desfixar el cartel que se puso, oficiando primero al Juez que lo mandó y haciéndole las reflexiones oportunas en reclamo de su jurisdicción que consideraba ofendida, y 
$17 \mathrm{f}$.

Decreto)

Relación)

$17 \mathrm{v}$.

Otro)

Auto)

$18 \mathrm{f}$. no faltar a las expresas y repetidas prevenciones de las cédulas que enseñan el modo de substanciar las competencias y aun a la atención que a qualquiera es devida y que entre los funcionarios públicos es necesaria y recomendable. Por no haber hecho hasta hoy tales reclamos, no hay en lo legal competencia, y el Fiscal juzga que deven reponerse al antiguo estado las cosas, mandando Vuestra Alteza, si fuete servido, que se fixe el auto de nuevo/por orden de esta Real Sala o por el Alcalde Ordinario, a quien así se le prevenga con la conminación oportuna o dando aviso de lo sucedido al Excelentísimo Virrey o del modo que a este Superior Tribunal pareciere más justo, pero extrañándole al Alcalde, en qualquier caso, la violencia e irregularidad de sus procedimientos. México, veinte y vno de enero de mil ochocientos diez y nueve. Berasueta.

México, veinte y dos de enero de mil ochocientos diez y nueve. Dése cuenta por el Relator y lo rubricaron. Cinco rúbricas. Francisco Calderón.

México, enero veinte y tres de mil ochocientos diez y nueve. Señores Governador, Mancilla, Medina, Torres: Vistos con lo pedido por el Señor Fiscal, se declara nulo, atentado y escandaloso el procedimiento del Alcalde Ordinario de Segundo Voto Don Luis Escovar. En consecuencia, buélvase a poner en el mismo lugar donde se havía fixado el auto proveído por/el Señor Alcalde de Corte, Juez en turno del Coliseo, Don Juan Ramón Osés, con el objeto de evitar el abuso y desorden público que en él se refiete, para lo que tubo competente jurisdicción, expresando el Escrivano de Cámara al pie de dicho auto que se pone de orden del Tribunal y que se aperciva mui seriamente al precitado Alcalde Don Luis Escobar, para que en lo succesivo se condusca con más arreglo y modetación, en inteligencia que por justas concideraciones no se hace toda la demostración que exige el caso. Licenciado Larrañaga.

En la Ciudad de México, a veinte y tres de enero de mil ochocientos diez y nuebe, los Señores Governador y Alcaldes del Crimen de la Real Audiencia y Chancillería de esta Nueva España, haviendo visto este expediente con que ha dado cuenta el Relator, dixeron: que devian declarar y declararon nulo, atentado y escandaloso el procedimiento del Alcalde Ordinario de Segundo Voto Don Luis Escobar, y en consecuencia devian mandar y mandaron se buelva a poner en el mismo lugar donde se havía fixado el auto proveído por el Señor Al- / calde de Corte, Juez en turno del Coliseo, Don Juan Ramón Osés, con el objeto de evitar el abuso y desorden público que en él se tefieren, 
Notoriedad)

$18 \mathrm{v}$.

Notificación)

Ynforme de 1a)

Real Sala )

$19 f$. para lo que tubo competente jurisdicción, expresando el Escrivano de Cámara al pie de dicho auto que se repone por orden del Tribunal, aperciviéndose mui seriamente al precitado Alcalde Don Luis Escobar, para que en lo succesivo se condusca con más arreglo y moderación, en inteligencia de que por justas concideraciones no se hace toda la demostración que exige el caso. Y por este auto así lo proveyeron y rubricaron. Cinco rúbricas. Francisco Calderón.

El Fiscal de Su Magestad queda enterado del superior auto que antecede. México, veinte y tres de enero de mil ochocientos diez y nueve. Vna rúbrica. En el mismo día yo, el Escrivano de / Cámara, para cumplir con lo mandado en el superior auto que antecede, pasé al Coliseo y, a presencia de su Administrador Don Francisco $V[r]$ bina, fixé la copia prevenida en el mismo lugar de donde se desfixó, quedando encargado el citado Administrador de cuidar que no se quite, firmando para constancia. De que doy fe. Francisco Antonio Cubiña. Francisco Calderón.

En seguida yo el Escrivano pasé al Jusgado del Alcalde Ordinario de Segundo Voto Don Luis Escovar, y, teniéndolo presente, le hize saber y notifiqué el contenido del superior auto que antecede, baxo el apercevimiento que incluye, de que enterado, dixo lo oye y firmó. Doy fe. Escobar. 18 Francisco Calderón.

Excelentisimo Señor. El auto proveído con fecha doce de enero próximo pasado por el Señor Alcalde del Crimen Don Juan Ramón Osés, Juez en turno del Coliseo, en que prohivió que los hombres saliesen a las tablas en trage de mugeres y las mugeres en trages de hombres, como estaba dispuesto, / fué dirigido a evitar en el acto de la representación vn escándalo público y la Sala está persuadida que el Señor Osés vsó de la jurisdicción que notoriamente le compete en haber dictado aquella providencia, sin que, por ella ni por haber prevenido fixar vna copia en el vestuario, a fin de que llegase a noticia de todas aquellas personas a quienes tocaba su cumplimiento, haya ofendido en lo más mínimo la autoridad del Superior Govierno ni tocado en las facultades que los Alcaldes Ordinarios de la Novilísima Ciudad exersan en el Coliseo, por razón de sus empleos. En quanto al primer punto, los documentos, que tiene a la vista el Tribunal, especialmente el Reglamento dado para la reforma del Teatro por el Excelentísimo Señor Conde de Galves, en once de abril de mil setecientos ochenta y seis, ${ }^{19}$ pruevan que ninguna intervención tubieron los Ministros de esta Real Sala en el Coliseo hasta que se puso en egecución la Real Cédula de 
quince de abril de mil setecientos noventa y dos, cuya copia ha remitido Vuexcelencia, porque, conciderada aquella Casa como finca propia del Hospital Real de Naturales, corrió $19 \mathrm{v}$. su administración y govietno/con todo lo anexo y dependiente al cargo del Oidor, Juez en turno de Hospitales. conforme a la Ley tercera, libro primero, título tercero de las Municipales; resultando también que en el govierno del Excelentísimo Señor Conde de Fuenclara se tubo por combeniente tomat la providencia de que el Corregidor y Alcaldes Ordinarios ayudasen al Oidor, Juez en turno de Hospitales, asistiendo aquéllos por escala, precisamente los días de comedia desde su principio hasta que se hubiese retirado el concurso para estar pronto a sosegar qualesquiera desórdenes que pudieran ocurrir, que de esta obligación fueron exonerados por decreto del mismo Excelentísimo Señor Virrey, de diez $y$ seis de junio de mil setecientos quarenta y seis, a consecuencia de las representaciones que

$20 \mathrm{f}$. los referidos Corregidor y Alcaldes Ordina- / rios le dirigieron: que, en vista de lo que expusieron los Señores Fiscales de esta Real Audiencia y Oidores Juezes en turno del Hospital de Naturales Don José Antonio Areche, Don Manuel Martín Merino, Don Diego Antonio Fernández de Madrid y Don Basilio de Villarraza y Venegas, se renovó la citada providencia por decreto de[1] Excelentísimo Señor Don Antonio María Bucareli, de diez y siete de marzo de mil setecientos setenta y nueve. y que, reasumida al Virreinato la jurisdicción privativa del Teatro por el Reglamento de que se ha hecho mérito, se confirió a quatro Directores de vna Sociedad de Accionistas que se formó para mantenerlo en el mayor decoro, concediéndoseles comición en quanto fuese necesario para arreglar la Compañía de Cómicos con todas sus incidencias-y dependencias, corregir y castigar a los Actores, Actoras y demás individuos que lo mereciesen; hacer observar respectivamente las disposiciones del Reglamento y poner en prisión a los contraventores; con reserva vnicamente al Corregidor y Alcaldes Ordinarios se prevenía sobre los delitos que pudieran perpetrarse / en el Teatro y hacer cumplir la tranquilidad, decencia y reglas dictadas respecto de los concurrentes. Pero el govierno del Teatro así establecido no duró mucho tiempo, porque la Sociedad de Accionistas se disolvió luego, cesaron por consiguiente los Directores y bolvió a ponerse al cargo del Oidor, Juez en turno de Hospitales, que lo fué primeramente el Señor Don Eusebio Bentura Beleña y des. pués el Señor Don Cosme de Mier, a quien el Excelentísimo Señor Virrey Conde de Revillagigedo mandó continuar en el turno, dándole comición separada sin limitación de 
$21 f$.

tiempo para Juez del Coliseo, en cuyo estado se comunicó la Real Cédula, por la qual el señor Regente Don Francisco Xavier de Gamboa y sus succesores en el empleo fueron nombrados Juezes del Hospital Real de Naturales, y aunque en su cumplimiento pretendió el citado Señor Regente que se le conservasen todas las facultades propias de los Juezes en turno del Hospital, conforme a la Ley de Yndias / en que se comprehendian las que havían egersido en la administración y govierno del Coliseo, como finca propia de aquel establecimiento, no se atendió su solicitud, lo que dió motivos al recurso que hizo a Su Magestad y a que se expidiese la expresada cédula de quince de abril de mil setecientos noventa y dos. Por ella tubo a bien Su Magestad declarar que al Regente de esta Real Audiencia, como Juez del Hospital, de quien es finca el Coliseo de Comedias, sólo compete en éste lo respectivo a obras, reparos y cobro de productos en que se arriende y que el componer la diferencia de los Cómicos, conocer de sus causas por razón de oficio, señalar la hora, cuidar de que las decoraciones sean honestas con lo demás anexo y dependiente, corresponde al Superior Govierno, añadiendo que a exemplo de Madrid concurran por turno semanario los Alcaldes del Crimen, a efecto de hacer observar con prontitud el buen orden, quietud y sosiego público durante la decoración y que la concurrencia del Juez del propio Teatro sea del Corregidor y Alcaldes Ordinarios de la Ciudad y no de los Alcaldes del Crimen. Determinada de este modo por la primera vez la / asistencia de los Ministros de esta Real Sala al Coliseo, como Juezes del público, con toda la autoridad y jurisdicción propias de su carácter, y trasladadas en parte al Corregidor y Alcaldes Ordinarios las facultades que antes havía egersido el Oidor, Juez en turno del Hospital de Yndios, en lo económico y guvernativo del Teatro, respecto de los Actores, Actrices y demás indivi duos de la Compañía Cómica y otras cosas pertenecientes a la economía del mismo Teatro, no es extraño que se hubiesen succitado algunas dificultades y disputas a las cuales se ocurrió por las providencias del Excelentísimo Señor Conde de Revillagigedo de diez y siete de matzo, tres y nueve de abril de mil setecientos noventa y quatro, 20 en que con arreglo al tenor literal de la cédula fundamental de la jurisdicción de los Alcaldes del Crimen en el Cqliseo $y$ de las Reales Ordenes de mil setecientos/cincuenta y tres, mil setecientos sesenta y seis y mil setecientos ochenta y seis dadas por los teatros de la Corte de Madrid que hoy forman las Leyes nueve, diez y once, libro séptimo, título treinta y tres de la Novisima Recopilación de Cas- 
tilla, se mandó que los Ministros de esta Real Sala, que por su turno deven asistir a todas las diverciones que ocurran en el Coliseo, cuiden de la observancia de quanto concierne a la seguridad, decencia y buen orden del público en todos los puntos comprehendidos en el testimonio que también obra en el expediente; como el que comienze la comedia vn quarto de hora después de la horación; que al extremo del tablado por toda su latitud se conserve la tabla para embarazar por este medio que se vean los pies de las Actrizes; que no haya extrépito que se haga molesto del concurso: que, desde que empiese la representación hasta que se concluyan sus respectivos actos, ninguno de los concurrentes tenga puesto el sombrero; que ningún hombre suba a la cazuela de las mugeres ni éstas a la de los hombres; que los coches lleguen con orden y en filas a la puerta del Coliseo/para que los tomen sus dueños conforme ocurran, sin que permanescan parados en la calle principal ni se atropellen vnos a otros para llegar con anticipación, a ecepción de los propios de los Alcaldes del Crimen; que éstos puedan hacer saber al público las disposiciones tomadas en la materia; y, en fin, que tengan conocimiento de las disputas criminales que se of rescan en el Coliseo, siendo perturbativas del buen orden, quietud y sosiego público dentro y fuera del vestuario. He aquí, pues, demarcadas con la mayor claridad las facultades que corresponden en el Coliseo al Superior Govierno, a los Alcaldes del Crimen, al Corregidor y a los Alcaldes Ordinarios de la Novilísima Ciudad. Nadie ciertamente se atreverá a negar que Vuexce$23 \mathfrak{f}$. lencia puede conocer de las diferencias de los Cómicos / y sus causas por razón de oficio, que está en su arbitrio señalar la hora que tenga por combeniente con arreglo a las circunstancias, para que empiese la representación y que de su autoridad pende vnicamente prescrivir las reglas más a propósito a fin de precaver qualesquiera desórdenes dentro y fuera del vestuario; pero tampoco se puede disputar a los Alcaldes del Crimen el conocimiento de todo quanto pertenesca en el caso, digo en el acto de la representación, al cumplimiento y egecución de lo que está mandado para la seguridad, decencia y buen orden del público ni, por consiguiente, la facultad de tomar providencia con los contraventores, valiéndose, en caso necesario, del auxilio de la tropa que a este fin concurre también al Coliseo y dando cuenta a la Sala, cuya autoridad representa en el mismo acto, para que los castigue a proporción de su culpa, como lo han practicado sin contradicción los actuales Ministros, ya mandando alzar el telón a la hora señalada por el Superior Govierno, ya providenciando sobre los desórdenes/ 
$23 \mathrm{v}$.

$24 \mathrm{f}$.

$24 \mathrm{v}$. ocurridos dentro y fuera del vestuario, y esto mismo está prevenido respecto de Madrid en el artículo veinte y tres de la citada Ley nueve y vno de la Novísima Recopilación de Castilla, asentando el Señor Don Antonio Martínez Salasar, Secretario de Su Magestad, en la Colección de Memotias y Noticias del Govierno Genetal y Politico del Consejo, capítulo quarenta y dos, que corresponde a la Sala de Alcaldes, entender y conocer de todas las causas que dimanasen de las questiones, disgustos y demás casos que ocurran en los Coliseos y que, por haber querido vn $\mathrm{Ca}$ pitular del Ayuntamiento de aquella Corte limitar la jurisdicción de los Alcaldes a sólo el patio y cazuela de las mugeres, se le hizo cargo de este exceso, por corresponder al Alcalde en los días de su asistencia el cuidado de todo el Coliseo y vestuario. En fin, al Corre-/gidor y Alcaldes Ordinarios de la Novilisima Ciudad, como Juezes del Teatro, sólo les compete la intervención en lo que toca a su govierno económico en la parte correspondiente a la representación, para que ésta se egecute con el decoro devido como el cuidar de que no haya discordias entre los individuos de la Compañía Cómica; que ninguno falte al cumplimiento de sus respectivas obligaciones sin motivo justo, que los mismos Juezes deverán calificar; que todo esté dispuesto y bien ordenado para la hora en que deve empezar la tepresentación y otras cosas a este tenor. Con lo dicho queda demostrado, a juicio de la Sala, la jurisdicción con que se proveyó el auto que ha dado motivo a la quexa dirigida a Vuexcelencia por los Alcaldes Ordinarios de la Novilísima Ciudad, que en el día egersen las funciones del Corregidor, y no es menos claro que la providencia es arreglada en quanto al segundo punto o la prevención de que se fixase copia de ella en el vestuatio, para que llegara por este medio a noticia de todos los individuos de la Compañía Cómica que devían cumplirla. Pudo / sin duda hacerse la notificación a cada vno de dichos individuos en su persona, como se verificó con el Asentista, ya estando aquéllos en sus casas, ya en qualesquiera otra parte, aun en el mismo vestuario; y pudo hacerse. fixándose copia de la providencia a la entrada del mismo Coliseo $y$ en parage donde pudiesen verla todos los concurrentes a él. Pero se trató prudentemente de evitar los embarazos e incombenientes de semejantes medios y se tomó el más sencillo que lo allanaba todo. Ya se ha visto que el vestuario no es vn lugar exento de la jurisdicción de los Alcaldes del Crimen y, quando lo fuera, nada importaría esta circunstancia para el caso de que se trata; dentro del Palacio donde havita Vuexcelencia, en las puertas de las 
$25 \mathfrak{f}$.

$25 \mathrm{v}$.

266 . mismas yglesias se fixan todos los días avisos y edictos citatorios/por mandado de los Juezes de Provincia y otros, sin que hasta ahora se haya imaginado que por este hecho se cometa alguna ofensa ni contra el respeto que se deve a las Casas Reales ni contra la inmunidad de las yglesias. Y, aun dentro de éstas, por mandado del Juez Secular, se puede hacer la citación para la causa que ante él puede, no se impidiendo los oficios divinos según $\mathrm{e}[\mathrm{n}]$ señan autores de la mexor nota. Con estos fundamentos devía descansar tranquilo el Señor Alcalde del Crimen Don Juan Ramón Osés, satisfecho de haber llenado vn dever tan importante al servicio de ambas Magestades en la prohivición de que se viesen en las tablas vn desorden, abominable aún entre los mismos gentiles, contrario a las buenas costumbres y expresamente prohivido por las leyes de la materia, cuya observancia en el acto de la representación es vn encargo particular de los Ministros de este Tribunal, quando cupo la noche del mismo día, doce de enero en que se / hallaba presidiendo el Coliseo y se fixó la copia del auto que se había arrancado por orden del Alcalde Ordinario de Segundo Voto Don Luis Escobar, poco rato después de haber empesado la representación, como certificó el Receptor de esta Real Sala, que asistió al Coliseo; y con el expediente original dió cuenta al Tribunal que desde aquí comensó a conocer del asunto, mandando hacer la averiguación de que resultó la certeza del hecho con las declaraciones de dos testigos y el informe del mismo Alcalde Ordinario. Este combiene con el Escrivano de su Asistencia en que, con todo conocimiento, dispuso que se le llevase la copia del auto para mandar bolverla a poner si era justo $y$, aunque añade que se le convenció por quantos alli estaban que no tocaba la determinación a la autoridad del Señor Ministro que presidía el Coliseo, ni podía mandarla fixar en el vestuatio sin vn notorio y violento despojo de la jurisdicción privativa que egercen los Alcaldes Ordinarios, en cuya quieta y pacífica poseción los han mantenido siempre repetidas resoluciones del Superior Govierno, de quien dependen inmedia-/ tamente y a quien corresponde el conocimiento; el hecho mismo, la declaración del Escrivano Zamorano y las palabras del infome están manifestando que el Alcalde Escobar, quando dió orden de que se llevara la copia de la providencia, no tubo otra mira que la de ostentar vna autoridad superior a la de los Ministros de la Sala, exponiendo la de este Tribunal a las murmuraciones de los concurrentes al Coliseo y a la rechifla de los mismos Cómicos, y que el hacer mérito en el indicado informe de 
$26 \mathrm{v}$.

$27 \mathrm{f}$.

las facultades de Vuexcelencia es vna invención posterior con que se ha creído cohonestar de algún modo el procedimiento y al mismo tiempo comprometer con Vuexcelencia a esta Real Sala. Si la providencia contubiera la prohivición de alguna cosa nueva o reglas que se mandaran observar en el Coliseo o si en ella se tratase del govierno económico de esta Casa, en quanto pertenece a la decoración, / pudiera decirse que estaban ofendidas las facultades de Vuexcelencia y la jurisdicción de los Alcaldes Ordinarios, que'se llama privativa en el informe. Pero no se concibe cómo pueda ser contrario ni a vna ni a otra autoridad el auto proveído, para que se evite vn pecado público, cuyo castigo en cumplimiento de la Ley veinte $y$ nueve, título diez y ocho, libro segundo de Yndias, pidió el Señor Fiscal, en caso de que llegara a cometerse a pretexto de lo ocurrido, luego que por la primera vez se le pasó el expediente. La Sala no duda vn momento que Vuexcelencia está penetrado de estas mismas verdades $y$ de que, aun quando se quiera suponer que el Alcalde Ordinario de Segundo Voto creyó que estaban ofendidas las facultades que le competen, no por eso dexaría de ser su conducta mui reprehensible. En este caso, como observa el Señor Fiscal en su segunda respuesta, devió haberse abstenido de desfixar el cartel que se puso, oficiando primero al Juez que lo mandó y haciéndole las reflexiones oportunas en reclamo de su jurisdicción que consideraba ofendida, y no faltar a las expresas / y repetidas prevenciones de las cédulas que enseñan el modo de substanciar las competencias, y aun a la atención que a qualquieta es devida y que entre los funcionarios públicos es necesaria y recomendable; y que se puede añadir que según la Ley octava, libro quinto, título nueve de la Recopilación de Yndias, 21 el Ministro o Tribunal que atentare o innovare, pendiente la competencia, por el mismo caso pierde el derecho que pudiera tener al pleito o negocio de que se tratare, y queda remitido a la jurisdicción del otro Ministro o Tribunal con quien compitiere. Además de esto, es constante que las leyes prohiven con el mayor tigor los medios de hecho o las violencias, especialmente en los Jueces, mandando que ante todas cosas se reponga lo que egecutaren por aquellos medios. Por todo to qual, el Tribunal, en vso de su jurisdicción, hizo en auto del dia veinte y tres del citado enero la calificación que merece el procedimiento del Alcalde de Segundo Voto Don Luis Escovar, declarándolo en su consecuencia nulo, atentado y escandaloso; mandando reponer copia del auto proveído por el Señor Ministro / Don Juan Ramón Osés en el mis- 
mo lugar donde se havía fixado y aperciviendo al mismo Alcalde Ordinario, para que en lo succesivo se condusca con más arreglo y moderación. Que es quanto tiene que exponer a Vuexcelencia esta Real Sala con remición del expediente original, no haciéndola del que se obró en cumplimiento de la Real Cédula de quince de abril de mil setecientos noventa y dos por no encontrarse en sus Árchivos. Dios guarde a Vuexcelencia muchos años. México, quatro de febrero de mil ochocientos diez y nueve. José Yáñez, Manuel Martínez Mancilla, Yldefonso José de Medina. Excelentísimo Señor Virrey Conde del Venadito.

Oficio)

$28 \mathrm{f}$.
Excelentísimo Señor. Esta Real Sala acompaña a Vuexcelencia original, en foxas cuarenta y seis, / el expediente instruido sobre que no se permita en el Coliseo que los hombres vistan el trage de mugeres ni éstas el de hombres, evacuado el informe que Vuexcelencia se sirvió pedirle en oficio de veinte $y$ cinco de enero último. Dios guarde a Vuexcelencia muchos años. México, quatro de febrero de mil ochocientos diez y nueve. José Yáñez, Manuel Martínez Mancilla, Yldefonso José de Medina. Excelentísimo Señor Virrey Conde del Venadito.

Concuerda con'su original que se debolvió a la Secretaría de Cámara y Virreynato a que me remito y, en cumplimiento de lo mandado en superior decreto, proveído en el quaderno corriente, doy el presente en México, a veinte y nueve de mayo de mil ochocientos diez y nueve. Andrés Hurtado. Corregido. 



\section{NOTAS}

\section{COMENTARIO}

1. Una beca dada en 1942 por el American Council of Learned Societies, Washington, D. C., me permitió reunir parte de los materiales usados en este estudio.

2. Consta el documento de 28 folios y se encuentra en el Legajo 252 , Expediente 10. Quiero manifestar mi agradecimiento a mis buenos amigos los señores Agustín Hernández y Manuel Camacho Herrera, quienes con suma bondad me hicieron conocer el expediente estudiado aquí y tuvieron la galantería de ayudarme a resolver varias dificultades en el original e hicieron todo lo posible para facilitar mi trabajo.

3. El expediente y mis notas servirán para mostrar que la cuestión de su jurisdicción en el Teatro requería atención desde hacía mucho tiempo. Sólo ocho días después del incidente descrito en el expediente ocurrió otro que puso en plena luz el conflicto de autoridad con la necesidad de aclaración por parte del Virrey. El Alcalde Ordinario don Juan Cervantes y Padilla, colega del señor Luis Escobar, ordenó que se previniese al individuo que habia de anunciar la comedia para el día siguiente, "que, si acaso arrojaban algún papel (como la noche antecedente), no le leyese". Al poco rato se supo que cierto sujeto había entregado dos sonetos, impresos en octavo, para que se leyesen a la hora del anuncio, diciendo que tenía licencia del señor Alcalde de Corte Don Manuel Mansilla. Este, al ser interrogado, respondió que no sabía nada de tal cosa ni estaba de semana y que debía preguntarse al señor Ramón de Osés sobre el asunto. El señor de Osés no tenía tampoco la menor noticia, pero pidió que le llevaran los sonetos para leerlos. Al asegurarse de que no contenían nada ofensivo, propuso que los leyesen en el Teatro para dar gusto al público. Participado el señor Cervantes y Padilla de la decisión, se negó a dar licencia para la lectura, a menos que el señor de Osés lo mandase expresamente. Este, viendo hecha la pregunta en esa forma tan directa, dió un paso atrás y rehusó dar la orden. En el último acto de la comedia, el Alcalde Ordinario, enterado de la mucha grita del auditorio que no dejaba continuar la representación, volvió a consultar al Alcalde del Crimen y, al fin y al cabo, se decidió a dejar leer los versos. Véase en Ramo de Historia, Diversiones públicas, tomo cCCCLXXXII, xiv, folios $22 \mathrm{f}-23 \mathrm{f}$. En su carta del 22 de febrero, remitida al Virrey, el señor Juan Cervantes y PadiHla manifestó los embarazos encontrados por los Alcaldes Ordinarios para dictar las providencias que creían convenientes al gobierno del Teatro y la falta de libertad que tenían para sostenerlas. Ibid., folio $24 \mathrm{f}-\mathrm{v}$.

4. Los reglamentos que regían en México estaban tomados casi en conjunto de los que se observaban en los teatros de Madrid, permitiéndose fumar, sin embargo, en los de la capital de Nueva España por lo popular del tabaco. Para los bandos y reales órdenes relativos a los teatros de Madrid, véase Leyes 9 . 10, 11 y 12, Título XXXIII Libro VII, en la Novísima recopilación de las leyes de España, Madrid, [1805?]. 
5. Para una historia muy completa del Coliseo, véase Manuel Mañón, Historia del Teatro Principal de México, México, 1932.

6. Desde el año 1601 en adelante procuraron las autoridades de Nueva España hacer que las actrices no representasen en vestido de hombre, juzgando tal costumbre lasciva y contraria a las reglas de la vida decente: "En la ciudad de México, a veinticuatro días del mes de enero de mil seiscientos y un años... ha sido informado Su Señoría que no se guardan [las limitaciones y calidades] en especial y cuanto a la decencia de la materia y lenguaje del traje de las mujeres, de que han resultado y resultan algunos inconvenientes de mucha consideración, $\mathrm{y}$ a que es justo prevenir para adelante; por tanto, ha acordado Su Señoría de mandar, como manda por este auto, a los autores de las dichas comedias, que primero y ante todas cosas que representen cualesquier comedias y entremeses, lo lleven al Provisor de este Arzobispado para que las vea, examine y apruebe, y en las que así se aprobaren y hubieren de representarse se guarde inviolablemente 1o que está ordenado y mandado sobre no representar mujer en hábito de hombre, ni usar de trajes desenvueltos en demasía, lascivos y deshonestos, ni contra lo que se debe guardar en actos públicos..." Del General de Parte, v, 272, impreso en el Boletín del Archivo General de la Nación. 1944, XV, 111. Véase también ibid., pág. 114. Una disposición parecida, relativa a las actrices en España, se remonta al año 1587: "Dase licencia para que puedà representar Angela Salomona y Angela Martineli, las cuales consta, por certificación del señor Alcalde Bravo, ser mugeres casadas y traer consigo sus maridos, con que ansí mismo no puedan representar sino en hábito y vestido de muger, y no de hombre, y con que de aquí adelante tampoco pueda representar ningún muchacho vestido como muger." Véase Cristóbal Pérez Pastor, Nuevos datos acerca del histrionismo español, Madrid, 1901, pág. 21. En el año 1641 volvió a insistirse en lo mísmo: "Qúe las mujeres representen en hábito decente de mujeres, y no salgan a representar en faldellín sólo, sino que por lo menos lleven sobre él ropa, baquero o basquiña, y no representen en hábito de hombres, ni hagan personajes de tales, ni los hombres, aunque sean muchachos, de mugeres." Véase Emilio Cotarelo y Mori, Bibliogtafía de las conttoversias sobre la licitud del teatto en España, Madrid, 1904, pág. 632. Fué modificada un poco dicha restricción por la Real Orden de 1653, admitiendo la necesidad de llevar tal disfraz en la representación de ciertas obras: "Os ordeno que enviéis órdenes a la Corona en todo aprieto (de suerte que se observen precisa $y$ indispensablemente), que ninguna mujer pueda salir al teatro en hábito de hombre, y que si huviese de ser preciso para la representación, que hagan estos papeles, sea con traje tan ajustado y modesto, que de ninguna manera se les descubran las piernas ni los pies, sino que esto esté siempre cubierto con los vestidos o trajes que ordinariamente usan, o con alguna sotana, de manera que sólo se diferenzie el traje de la cintura arriba." Véase ibid., pág. 635. En 172.5 se especificó que ellas, en caso de representar papel de hombre, saliesen con basquiña que cayese "hasta el zapato o empeine del pie". Véase ibid., pág. 641 .

7. El Expediente, fol. $4 \mathrm{v}$.

8. Ya en el año de 1615 , con el fin de mejorar las condiciones en los teatros de Madrid, se ordenó a los Alcaldes de Corte que estuviesen presentes durante las funciones dramáticas para mantener el buen orden: "Que en cada teatro aqui en la Corte asistan un alguacil de ella, cual fuete nombrado (además de Juan Alicante, alguacil de la casa y corte de S. M., el cual como hasta aquí. ha de asistir en ellos conforme a la Cédula Real que tiene de. S. M., de manera que pueda acudir a cualquiera de los corrales donde más necesidad hobiere), y los otros dos alguaciles por el tiempo que fuesen nombrados cada uno asista en el teatro que le fuere señalado, y no pueda ir de uno a otro; y todos han de tener cuenta con que no haya ruidos, ni alborotos, ni escándalos, y que los hombtes y mugeres estén apartados, así en los asientos, como en las entradas y salidas, para que no hagan cosas deshonestas y para que no consientan entrar en los vestuarios persona alguna fuera de los representantes. $Y$ que estos dos alguaciles sirvan 
no más que dos meses, y cumplidos se muden otros dos; y para que asimismo hagan que entren y salgan temprano de las comedias, de suerte que salgan de día. y que no se abran los teatros antes de las doce del día. Que los autores y sus compañías no representen en esta corte en casas particulares sin licencia del Consejo. y en los ensayos que hicieren en sus casas, no admitan gente alguna a verlos hacer." Véase Cotarelo y Mori, Bibliografía de las controversias, etc., págs. 626627. La Real Orden del año 1765 agregó la especificación de que asistiese diariamente a las representaciones de cada teatro un Alcalde de Corte. Véase ibid., pág. 657. Volvió a referirse a las facultades de los'Alcaldes de Corte en el Reglamento del año 1786 , señalando que éstos tuvieron "privativamente la jurisdicción y autoridad en el acto de las representaciones..." Véase Art. 1, Ley 12 . Tít. XXXII, Libro VII, en la Novísima recopilación, etc.

9. Durante los dos primeros siglos, empezaba la representación en los teatros de España a las tres de la tarde en invierno y a las cuatro en primavera y verano. Desde 1768 ya se representaba en las noches de estío, pero no se hicieron generales las representaciones: nocturnas hasta principios del siglo XIX. Véase Emilio Cotarelo y Mori, Matia Ladvenant y Quirante (Estudios sobte la historia del atte escénico en España). Madrid, 1896, pág. 22. De acuerdo con el decreto del Conde de Revillagigedo, expedido el 17 de marzo de 1794, habían dado invariablemente los Alcaldes del Crimen la orden para que empezase la comedia, pero la noche del 28 de octubre de 1798 se presentó un Alcalde Ordina. tio, afirmando que le correspondía esa función. E1 Virrey resolvió que los dos ramos debieran encargarse de la obligación, admitiendo el derecho de los Alcaldes del Crimen de disponer que comenzase la función e instando a los Ordinarios que cuidasen que los cómicos se hallaran prontos a la hora señalada. Véase Diversiones públicas, tomo CCCCLXXIX, xvii, 56 f'ojas.

10. "Este teatro se abrirá todos los años en 19 de octubre y se cerrará en 1 o de julio, empezando las representaciones a las siete y media de la noche y acabándose forzosamente antes de las once, para dar tiempo a que se recojan los espectadores y que no se perjudique a los cómicos españoles que representan por las tardes en el discurso del año, y sólo por las noches en los tres meses de verano." Véase "Reglamento para el mejor orden y policía del Teatro de la Opera, cuyo privilegio se ha servido conceder el Rey a los 'Reales Hospitales, aprobado por S. M. y comunicado a la Sala de Alcaldes para su publicación. en virtud de Real Orden de once de diciembre de mil setecientos ochenta y seis", reimpreso por Cotarelo y Mori, en Bibliografía de las controversias, etc., pág. 674 .

11. Gala - "Se llama también el particular aplauso, obsequio u honra que se hace a alguno, en atención a lo sobresaliente de su mérito, acciones o prendas, en competencia de otros; y assí se dice llevarse la gala, cantar la gala, etc. Y también el premio especial que se da por estas mismas causas. En este sentido es mui usado en los Reinos de las Indias." Véase Diccionario de Autoridades.

12. El Expediente, folio $10 \mathrm{v}$.

13. Ibid, folio $11 \mathrm{f}$.

14. "Es sabido que desde el siglo XVI los hospitales de la corte gozaron la exclusiva de los espectáculos teatrales, con cuyos rendimientos sufragaban sus gastos. Que, a fin de no pagar alquiler de locales, compraron en 1579 unos solares en las calles de la Cruz y del Príncipe, y en ellos levantaron sus teatros o cotrales ..." Véase Cotarelo y Mori, Matía Ladvenant, etc., pág. 19. El primer teatro en México, que perteneció al Hospital Real de Indios, ya funcionaba en el año de 1627, y con toda probabilidad varios años antes. Véase mi estudio "Notas relativas a los corrales de la Ciudad de México, 1626-1641", Revista Iberoamericana, 1941, II; 133-138. Parte de los rendimientos del Coliseo, cuando no se administrase con pérdida, ayudaba a sostener el Hospital. Por el año de 1776 la Casa de Comedias rindió al Hospital cuatro mil cuatrocientos pesos. Véase Constituciones y ordenanzas pata el régimen y govierno del Hospital Real y General de los Indios de esta Nueva España, mandadas guardar por S. M. en Real Cédula de 27 de octubre del año de 1776 , Méxíco, 17.78, tratado Iọ, 
primer capítulo, pág. 1, en Instrucciones, ordenanzas, reglamentos, constituciones, tomo II de la Colección Genaro García en la Biblioteca de la Universidad de Texas. Pero, en cambio, en 1814 se hallaban tan escasos los fondos del Hospital que el Virrey permitió que se representasen piezas teatrales durante la cuaresma: "El Excelentísimo Señor Virrey, sin embargo de serle muy repugnante el permitír que en los días de Cuaresma haya representaciones en el Teatro, se ha servido condescender a ello, penetrado de las escaseces que experimenta el Hospital General de Naturales de la falta de arbitrios para socorrer a sus infelices enfermos y de la contribución que ha of recido a beneficio de ellos el Assentista Don Mariano González de la Rosa en la contrata que ha celebrado a este efecto con conocimiento del Excelentisimo Ayuntamiento Constitucional; y, a consecuencia del enunciado superior permiso, se representarán en los domingos, martes. jueves y sábados de la presente Cuaresma, empezando desde el primer domingo de ella y concluyéndose el jueves de la semana de Dolores, algunos dramas, como coloquios y autos sacramentales, $\mathbf{u}$ otras diversiones como las de sombras chinescas, juegos de mano, maromas, etc., según convenga al Contratista, quien por separado avisará al público los precios que ha estipulado con el Excelentísimo Ayuntamiento en cuanto a palcos, lunetas y demás departamentos del Teatro." Véase Gaceta del Gobierno de México, 26 de febrero de 1814 , no. 532 , V, 228. 15. Decotación - "La mutación de escena y su adorno en las representaciones teatrales." Véase Diccionario de la lengua castellana, por la Academia Española, 7 a edición, 1824.

16. El Expediente, folio $13 \mathrm{f}-\mathrm{v}$.

17. Ibid., folio $15 \mathrm{v}$.

18. Ibid., folio $24 \mathrm{f}$.

19. Ibid., folio $26 \mathrm{f}$.

20. Véase Diversiones públicas, tomo CCCCLXXXII, Xv, folios $28 \mathrm{f}-35 \mathrm{v}$. 21. Véase Diversiones públicas, tomo CCCCLXXXII, xv, folios $36 \mathrm{f}-37 \mathrm{v}$.

\section{EXPEDIENTE}

1. Hay otras dos copias de este auto en Diversiones públicas, tomo CCCCLXXXII, xv, folios $2 f$ y $10 \mathrm{f}$. Según la certificación escrita al fin de la segunda, fué prevenido el 23 de enero por la Real Sala del Crimen que volviese a ponerse la original en el vestuario.

2. En el informe de fecha 13 de enero, que envió el señor Escobar al Virrey, detalló más el motivo de su acción, basando su defensa en los capítulos de la Real Cédula, expedida en Aranjuez. Escribió entre otras cosas: "Hoy me he confirmado en el concepto que desde luego formé en el acto, pues por la Real Cédula, fecha en Aranjuez, a 15 de abril de 1792, en que se mandó cesar la co. misión del Juez del Teatro, conferida por el Excelentísimo Señor Virrey Conde de Revillagigedo, se declaró correspondiente a este Superior Govierno la jurisdicción concerniente a él, que quedó al cargo del Corregidor y Alcaldes Ordinarios, mediante a que la alta dignidad y vastas atenciones de los Excelentísimos Señores Virreyes, no les permiten su inmediato exercicio, previniéndose sólo que a exemplo de la corte de Madrid, concurriesen por turno semanario los Señores Alcal des del Crimen, a efecto de hacer observar el buen orden, quietud y sosiego público durante la decoración. Conforme a esta soberana determinación ha estado siempre a cargo del Corregidor y Alcaldes Ordinarios, baxo la inmediata dependencia de Vuestra Excelencia, el cuidado del buen orden en lo interior del Teatro, de que las representaciones sean honestas y decorosas, de que los actores y demás dependientes cumplan sus respectivas obligaciones, de dar la hora para que comienzen las funciones $y$, en una palabra, de quanto es anexo e incidente a ello, en lo que la superioridad no ha tenido a bien tomar inmediato conocimiento." Véase Diversiones públicas, tomo CCCCLXXXII, $\mathrm{xv}$, folio $3 \mathrm{v}-4 \mathrm{f}$. La carta, escrita para acompañar el informe al Virrey, se halla en folios $11 \mathrm{f}-12 \mathrm{f}$. El Código 
de Reforma, sometido en el año de 1806 por el Alcalde del Crimen don Manuel del Campo y Rivas habria abrogado en mucho las estipulaciones de la Real Cédula de 1792, quitando varias facultades a los Alcaldes Ordinarios, las que serían absorbidas por los del Crimen. De manera que a éstos, no estando presentes los Virreyes, les tocaría el derecho de mandar que comenzase la función a las siete y media de la noche, la hora señalada; de entender y conocer de las causas que resultasen de riñas, delitos o desórdenes de los actores, dentro o fuera del vestuario; de ver que los actores cumpliesen con sus obligaciones. Véase ibid., tomo CCCCLXXIII, xvi, folios 13f-14f. Informado el Alcalde Ordinario don Luis Escobar de que había habido varias disputas con los Alcaldes del Crimen sobre la cuestión de jurisdicción en el Coliseo, escribió a varios antecesores, rogando que le explicasen la resolución de las dificultades anteriores. José Juan Fagoaga contestó que el Virrey don José de Iturrigaray, con el fin de resolver el problema de las facultades de los dos ramos, declaró dos veces en 1807 "que el govierno y jurisdicción del patio era de los Señores Ministros del Crimen y la de lo interior del Teatro de los Alcaldes Ordinarios", véase ibid., tomo CCCCXXXII, xiv, folio 4f. El Alcalde del Crimen don Manuel del Campo y Rivas había planteado el problema sustentando la proposición que sus facultades, como substituto del Regente, eran más amplias, en vista de que el Teatro entonces se administraba por cuenta del Hospital, en vez de ser arrendado por un particular. Lo que irritó al Alcalde del Crimen fué que el Alcalde Ordinario prohibió que se efectuase la repetición de bailes sin su orden. El Fiscal dudó que las disposiciones de la Real Cédula fuesen adaptables a las circunstancias, estando entonces el Coliseo bajo la dirección del Hospital, y propuso que no se limitasen las funciones del señor Campo y Rivas a los puntos de obras, reparos y cobro de productos. También revelaron sus palabras, escritas en el mes de enero de 1807 , que no se había podido rematar en arrendamiento el Coliseo, a pesar de prolijas y repetidas diligencias. Concluyóse el caso, admitiendo la renuncia del señor Campo y Rivas en su capacidad de substituto del Regente del Hospital. Véase ibid., tomo CCCCLXVIII, xii, 30 fojas. El Conde de la Cortina respondió que, en consecuencia de una discusión surgida en el año de 1811, hizo presente a un Alcalde de la Real Sala "que era privativo del Corregidor y Alcaldes Ordinatios la administración de justicia y de más ocurrencias en aquel parage, así como lo era de los Señores Ministros en turno todo que ocurriese de tablas afuera". Véase ibid., tomo CCCCLXXXII, xiv, folio 6f. Certificó también el Escribano del Teatro - había tenido la plaza desde 1802-que durante su oficio el Corregidor y los Alcaldes Ordinarios habían sido reconocidos como Jueces del Teatro, encargados de arreglar las cosas de los actores y de asistir diariaménte por semanas a las funciones. Añadió que los expedientes en su poder demostraron "que los Excelentísimos Señotes Virreyes, siempre que su superioridad ha dictado alguna providencia, para su cumplimiento, to han dirigido al Juez de semana en el Teatro". Véase ibid., folio 10v. En una larga respuesta del 6 de febrero, al oficio del Virrey, los Alcaldes Ordinarios le expusieron los argumentos que habían podido reunir a favor de su jurisdicción en el interior del Teatro: que la Real Cédula de Aranjuez previno que los Alcaldes del Crimen asistiesen al Teatro a hacer observar el buen orden durante la representación, pero agregó que la concurrencia de Juez del Coliseo fuese del Corregidor y Alcaldes Ordinarios; que el Virrey Conde de Revillagigedo en un Reglamento de 28 de marzo de 1794 declaró que "el arreglo de las decoraciones, señalamiento de días y horas de la representación, con todo lo demás anexo y concerniente al gobierno económico de las diversiones teatrales, era privativamente de esta superioridad, sin que compitiese a ninguno de los otros Jueces del Coliseo, añadiendo que en consecuencia de esta declaración había subdelegado todas sus superiores facultades, relatibas a estos puntos en el Señor Corregidor"; que otros Virreyes, en otros varios casos que no llegaron a formalizarse, renovaron la delegación de sus superiores facultades en el Corregidor y los Alcaldes Ordinarios; que la noche del 28 de julio de 1811 "aconteció también que el Señor Don Miguel Bachiller, entonces Alcalde 
de Corte, previno no se concluyese la comedia por estarse acabando las luces; cuya disposición reclamada por el Teniente Letrado que desempeñaba las veces del Corregidor, se le conbenció al Señor Alcalde de Corte no corresponder sino al corregimiento, por cuyo medio quedó salva e intacta la jurisdicción de éste sobre el particular, no formalizándose competencia por haber cedido aquel Señor Ministro". Véase ibid., folios $12 \mathrm{f}-21 \mathrm{f}$.

3. Ocupados en el original.

4. E1 aviso al público que dió los capítulos, impresos con pocas excepciones en el idéntico lenguaje del expediente ("Que los mozos que venden aguas... no se ha de instar a ello. Que, siendo tan general el vso del tabaco... de los propios de los Señores Jueces"), llevó la fecha de 28 de abril de 1794 y fué expedido durante la administración del Conde de Revillagigedo. Un ejemplar de este aviso se conserva en Bandos y teglas impresas, XVII, 311.

5. "Ordenamos a los Fiscales que tengan gran cuidado de la defensa y conservación de la jurisdicción, patronazgo y hacienda real y castigo de pecados públicos y de darnos cuenta con particular relación de todo lo que en esto hubiere y de quanto más convenga a nuestro real servicio." Véase la Recopilación de leyes de los reynos de las Indias, Madrid, 1791, 4a impresión, I, 410.

6. Para la parte de la instrucción del Conde de Revillagigedo relativa a las facultades de los Alcaldes del Crimen, véase abajo nota 15. El Marqués de Branciforte delegó al Corregidor y los Alcaldes Ordinarios, como oficiales bajo su inmediata dirección, el cuidado del interior del Teatro: "... pero reitero a Vuestra Metced que con ningún motivo ni pretesto han de permitirse en el Teatro sin orden superior mía otras diversiones que las contratadas con el $\mathrm{Ym}$ presario, entendido Vuestra Merced de que la delegación que turna entre el Corregidor y los Alcaldes Otdinarios para el cuidado y vigilancia de lo interior del mismo Teatro, está únicamente sujeta al Superior Gobierno que la delega, conforme a la Real Cédula de la materia, y debe por esto dársele cuenta de todas las ocurrencias que lo merescan, consultándole lo que necessite su autorizada determinación, tomándola el Juez Delegado por sí solamente en los casos de urgencia que no den lugar a esperarla, pero avisándolo después, para que recaiga la superior indispensable aprobación; todo lo que servirá a Vuestra Mercé y a sus compañeros de gobierno en lo subcesivo. Dios guarde a Vuestra Metced muchos años. Orizava, veinte y dos de febrero de mil setecientos noventa y ocho. Branciforte." Véase Diversiones públicas, tomo CCCCLXXIX, xvii, folios $21 \mathrm{f}-22 \mathrm{f}$.

7. pertenecet en el original.

8. trantotno en el original.

9. encuentran en el original.

10. ayudándose en el original.

11. cortado en las otras copias.

12. La carta, en que el Conde de Revillagigedo participó a don Cosme de Mier que le habia nombrado Juez del Teatro sin límitación de tiempo, se conserva en Diversiones públicas, tomo CCCCLXXIlI, ix, folio $35 \mathrm{f}$.

13. constaba en las otras copias.

14. reservado en dos de las otras copias.

15. Otras tres copias de esta Real Orden se hallan en el Archivo General de la Nación: Reales Cédulas y Otdenes expedidas al Exmo. Sot. Vittey Conde de Revillagigedo, 1792, tomo CLI, folios $372 \mathrm{f}-375 \mathrm{v}$; Diversiones públicas, tomo CCCCLXXXII, Xv, folios $6 \mathrm{f}-8 \mathrm{f}$ y tomo CCCCLXXIII, $\mathrm{xvi}$, folios $72 \mathrm{f}, 76 \mathrm{v}$. En el informe dejado a su sucesor, el Conde de Revillagigedo defendió su actitud, presentando en detalle su punto de vista y sus razones: "Está el Hospital de Yndios baxo la inmediata protección de los Virreyes en esta Capital y antiguamente nombraban un Oidor en turno, en quien delegaban toda su autoridad para todas aquellas funciones, que era imposible que asistiesen personalmente. Posteriormente vino una Real Cédula con fecha 21 de septiembre de 91 , nombrando al Regente de esta Real Audiencia por Juez Conservador del mismo Hospital, y este nombramiento ha sido origen de no pocas dificultades, principalmente 
sobre la intervención que debe tener en el Coliseo donde se representan las comedias y que es una de las mejores fincas del Hospital. Estaba antes arrendado a un asentista y habiéndose concluido el tiempo del asiento en el año de 91 , no hubo postor que pasase de la cantidad de quatro mil pesos, por lo que dispensando la prohivisión dispuse que se administrase y se ha hecho con un tan feliz éxito, que en el año de 92 dexó más de once mil pesos de ganancia líquida y en el de 93 más de nueve mil pesos. En todo lo judicial que se ofrecía, y aun en lo directivo en tiempo de los Asentistas, conocía un Oidor de esta Real Audiencia por comisión del Virrey, y lo económico era del cargo del Impresario, como ahora lo es del Administrador del Hospital. Ofrecióse duda en estas circunstancias a1 Regente de la Audiencia, creyendo corresponderle las facultades de Juez del Teatro $\mathrm{y}$, habiendo representado a la Corte, vino la Real Cédula de 19 de abril de 92 en que se declaró que la asistencia al Teatro debía ser del Corregidor y Alcaldes Ordinatios y que también debían asistir los Alcaldes de Corte por su turno, para atender al buen orden y quietud pública, que el superior gobierno debía conocer en todo lo gobernativo y el Regente pudiera asistir, quando quisiese, al Teatro con el Mayordomo del Hospital en el Palco que éste tuviere. Nacieron muchas dificultades sobre la inteligencia y cumplimiento de esta Real Cédula, a representación de los Alcaldes Ordinarios. Corregidor y demás interesados y habiendo sido necesario oír a todos a pedimento del Fiscal de lo civil, se substanció y resolvieton las dudas, poniéndose en práctica el nuevo plan desde abril de este año." Véase en El Archivo Municipal Ynstrucción teservada del Reyno de Nueva España que el Excelentísimo Señot Conde de Revillagigedo dió a su sucesot en el mando el Excelentísimo Señor Marqués de Brancifotte, tomo I, párrafos $50-55$.

16. "Igualmente serán responsables los autores a la nota que pudiera causar qualquiera Cómica de su Compañía que saliere a las tablas con indecencia en su modo de vestir, sin permitir representen vestidas de hombre, si no es de medio cuerpo arriba." Véase Art. 20, Leyes 9 y 10 . Tít. XXXIII, Libro VII, en la Novísima recopilación de las leyes de España. La Ley 11 no tiene nada que ver con las facultades de los Alcaldes de Corte.

17. "Los Alcaldes, en sus respectivos días de asistencia a las comedias. empleen todo su cuidado en la observancia de lo referido, como tan importante al servicio de ambas Magestades, desempeñando este particular encargo con el acreditado zelo que acostumbran, tomando providencia con los contraventores, para que la Sala los castigue a proporción de su culpa; y si fueren personas que por su empleo o caráctet merezcan ser distinguidas, y no bastaren los atentos y cortesanos oficios del Alcalde para su moderación, dará éste cuenta, luego que se acabe la comedia, al Señor Gobernador del Consejo, para que lo ponga en noticia de S. M." Cf. Art. 23, Leyes 9 y 10 , Tít. XXXIII, Libro viI, en la Novísima tecopilación de las leyes de España.

18. Notificado el Alcalde Ordinario de Segundo Voto de la determinación de la Real Sala y agraviado por su censura, rogó, en una exposición bastante larga del 25 de enero, que el Virrey se sirviese resolver los particulares de su jurisdicción. Véase Diversiones públicas, tomo CCCCLXXXII, xv, folios $19 \mathrm{f}-22 \mathrm{v}$.

19. Varias copias del reglamento de 11 de abril de 1786 , expedido por el Virrey conde de Gálvez para la dirección del Coliseo en lo económico, gubernativo y jurisdiccional, están en el Archivo General de la Nación. Consta de 28 páginas y 41 capítulos. Véase Bandos y teglas imptesas, tomo XIV, $62 \mathrm{f}-75 \mathrm{v}$; Diversiones públicas, tomo CCCCLXXIII, xvi, $77 \mathrm{f}-90 \mathrm{v}$; etc. Mañón lo publicó integro. Véase op. cit., págs. 21-33.

20. "Con esta fecha prevengo al Administrador del Coliseo lo siguiente: En mi oficio de veinte $y$ ocho de marzo próximo pasado, dije a Vd, que havía declarado en diez y siete del mismo que el arreglo de las decoraciones, seña [lar† los días y horas de representación y todo lo demás anexo y conserniente al govierno económico y governativo de las diverciones teatrales era privativamente de esta Superioridad, sin que alguno de los Juezes pueda por sí tener intervención 
de formar o reformar las Compañías de Cómicos o Bailarines, elejir piezas, asignar salarios y otras cosas de esta clase, pues durante la administración serán al cuidado de ésta y en caso de remate al del Asentista y siempre con la devida sujeción al govierno. En consecuencia de esta declaración, he subdelegado todas mis facultades relativas a estos puntos en el Señor Corregidor de esta Capital. quien deverá resolver por sí en las ocurrencias comunes, dándome cuenta para mi resolución de las extraotdinarias... México, veinte de abril de mil setecientos noventa y quatro. Revillagigedo." Véase Diversiones públicas, tomo CCCCLXXIX, xvii, $20 \mathrm{f}-\mathrm{v}$.

21. "Por evitar los inconvenientes que resultan de las competencias de jurisdicción, que muchas veces se mueven entre los Jueces, sin otro fin que sustentar y defender sus contiendas y porfías, hemos resuelto que el Ministro o Tribunal que atentare o innovare, pendiente la competencia, por el mismo caso pierda el derecho que pudiera tener al pleyto o negocio de que se tratare y quede remitido a la jurisdicción de el otro Ministro o Tribunal con quien compitiere. $\mathrm{Y}$ 'mandamos a los Vireyes (sic), Presidentes, Oidores, Alcaldes de el Crimen, Gobernadores y Capitanes Generales de qualesquier partes de nuestras Indias, Armadas y Flotas de la Carrera y a todos los demás Jueces de ellas que así lo guarden y cumplan." Véase Ley 8, Tít. IX, Libro V, en la Recopilación de leyes de los teynos de las Indias, Madrid, 1791, 4 a impresión, II, 156.

\author{
HaRvey L. Johnson, \\ Northwestern University.
}

